Research Article

Elsi Kaiser*

\title{
Effects of perspective-taking on pronominal reference to humans and animals: Logophoricity in Finnish
}

https://doi.org/10.1515/opli-2018-0031

Received December 19, 2017; accepted August 28, 2018

Abstract: This paper investigates the logophoric pronoun system of Finnish, with a focus on reference to animals, to further our understanding of the linguistic representation of non-human animals, how perspective-taking is signaled linguistically, and how this relates to features such as [+/-HUMAN]. In contexts where animals are grammatically [-HUMAN] but conceptualized as the perspectival center (whose thoughts, speech or mental state is being reported), can they be referred to with logophoric pronouns? Colloquial Finnish is claimed to have a logophoric pronoun which has the same form as the human-referring pronoun of standard Finnish, hän (she/he). This allows us to test whether a pronoun that may at first blush seem featurally specified to seek [+HUMAN] referents can be used for [-HUMAN] referents when they are logophoric. I used corpus data to compare the claim that hän is logophoric in both standard and colloquial Finnish vs. the claim that the two registers have different logophoric systems. I argue for a unified system where hän is logophoric in both registers, and moreover can be used for logophoric [-HUMAN] referents in both colloquial and standard Finnish. Thus, on its logophoric use, hän does not require its referent to be [+HUMAN].

Keywords: Finnish, logophoric pronouns, logophoricity, anti-logophoricity, animacy, non-human animals, perspective-taking, corpus

\section{Introduction}

A key aspect of being human is our ability to think and reason about our own mental states as well as those of others, and to recognize that others' perspectives, knowledge or mental states are distinct from our own, an ability known as Theory of Mind (term due to Premack \& Woodruff 1978). Human language has a variety of devices that a speaker (or writer) can use to signal that what they are expressing is another individual's perspective or mental state, such as syntactic embedding under verbs of communication and mental state (e.g. John said/thinks that he will win the race). In some languages, morphologically distinct logophoric pronouns are used to indicate that the speaker is conveying some other person's speech, thoughts or feelings.

However, how do we refer to sentient non-human creatures who presumably also experience different mental states? Do we linguistically signal shifts in perspective to non-human animals' mental states as well? The way in which humans regard the distinction between humans and other animals is complex. On

Article note: This paper belongs to the special issue on Effects of Animacy in Grammar and Cognition, edited by Diane Nelson and Virve Vihman.

*Corresponding author: Elsi Kaiser, Department of Linguistics University of Southern California, Los Angeles, United States,

E-mail: emkaiser@usc.edu 
the one hand, humans tend to view some animals - especially household pets like cats and dogs - as being 'like us' and often attribute human-like mental states and abilities to them (e.g. Eddy et al. 1993, Epley \& Waytz 2010; see also Heider \& Simmel 1944, Sealey 2018). On the other hand, human societies often draw a sharp line between humans and (most) non-human animals: animals are not usually viewed as having legal rights in the way that humans are, for example (see e.g. Herzog 2010, Arluke \& Sanders 1996 for discussion). Thus, in some contexts we seem very willing to view animals as sharing the human ability for mental states such as happiness, regret, guilt, responsibility, and so on, but in other contexts we avoid regarding animals as creatures capable of having inner lives (e.g. Herzog 2010). It is worth noting that the focus of this paper is not the question of whether animals actually experience the kinds of mental states that humans do - that is a question for researchers working in animal cognition. My focus instead is on how humans use language - especially features of language associated with key human abilities such as Theory of Mind - when talking about non-human animals, and what this can tell us about how perspective-taking is signaled linguistically, how it relates to features such as [+/-HUMAN], and more generally how language treats (relatively) fixed features such as [+/-HUMAN $]^{1}$ relative to more changeable properties such as being the perspectival center at a particular point of the discourse or narrative.

Given that language offers us a tool for signaling reference to another person's mental state, namely logophoric pronouns (discussed in Section 2), the question arises of whether this tool can also be used for talking about animals' mental states. Logophoric pronouns are specialized forms that refer to the 'subject of consciousness', i.e. the person whose speech, thoughts or feelings are being reported (e.g. Hagège 1974, Clements 1975, Sells 1987, Culy 1994). Thus, we can ask whether logophoric pronouns seek a [+HUMAN] antecedent whose mental state or perspective is being conveyed - i.e., a [+HUMAN] referent who is also the logophoric/perspectival center? Or do logophoric pronouns simply seek to refer to the logophoric perspectival center, even in a context where that logophoric center is [-HUMAN]? Prior work on logophors has identified different perspectival components to which they can be sensitive (e.g. Sells 1987 on self, source and pivot; Charnavel \& Zlogar 2015 on attitude holder, empathy locus and deictic center), but the question of whether logophors specifically target humans compared to non-human animals has not been systematically investigated from a crosslinguistic perspective (for Finnish, see Laitinen 2002, 2009, 2012; for related work, see Charnavel \& Sportiche 2016 on inanimates which cannot be logophoric centers).

Finnish - a Finno-Ugric language - is especially well-suited for investigating this question because colloquial Finnish is claimed to have a pronoun with logophoric properties which - intriguingly - has the same form as the human-referring pronoun used in Standard Finnish, hän (she/he; Finnish pronouns are gender-neutral). Thus, Finnish allows us to ask whether a pronoun, hän, that at first glance is featurally specified to seek [+HUMAN] referents, can also be used for [-HUMAN] referents when these referents are logophoric centers. In other words, what matters more, being [+HUMAN] or being the logophoric center? This question also relates to broader issues concerning semantic and pragmatic features, such as the extent to which discourse-semantic features such as logophoricity can 'overpower' arguably more immutable semantic features such as the [+/-HUMAN] distinction.

Given that thinking, speaking and mentalizing are fundamentally human traits, it would not be surprising if logophoric pronouns were specialized for exclusively human reference. Many other aspects of grammar, much less closely related to human cognition, clearly track the human/nonhuman distinction (see e.g. Siewierska 2004).

When we consider reference to animals, it is important to address the phenomenon of anthropomorphism of (or personification of) animals. From a linguistic perspective, it is possible to have contexts where animals - referents that normally have the feature [-HUMAN] - are treated grammatically as being [+HUMAN] in all (if not most) syntactic, pragmatic and semantic respects. Building on de Swart \& de Hoop (2018), such

1 For present purposes, I assume that, on the grammatical level, [+/-HUMAN] is a binary feature - but this does not preclude gradience outside the grammar. Conceptually, the extent to which a particular entity is regarded as (non-)human may well be a gradient matter. Relatedly, on the topic of animacy more generally, de Swart \& de Hoop (2018) state that "even though conceptually animacy may be a gradient notion, linguistically it manifests itself in a discrete (binary) way due to the fact that the phenomena in which animacy is involved are binary" (de Swart \& de Hoop 2018:4, but see also Nelson \& Vihman 2018 for evidence from languages with noun classes indicating that a purely binary approach in the grammar may not be sufficient). 
referents could be regarded as having undergone a semantic type shift from one ontological entity subtype to another: from $e_{\text {animate }}$ (the entity type for non-human animals) to $e_{\text {human }}$ (the entity type for humans). In cases where an animal referent has undergone this kind of type shift and is grammatically consistently treated as [+HUMAN], we cannot draw any conclusions about whether logophoric pronouns can refer to [-HUMAN] referents. This is because in these contexts, it is to be expected that even if logophoric pronouns are specified for [+HUMAN] referents, they could still be used to refer to these type-shifted animal referents. As a result, these are not the contexts that are of interest to us in this paper.

Crucially, there are also situations where animals have not been 'grammatically transformed' into [+HUMAN] referents, but are nevertheless represented as having mental states. Consider a text where a non-human pronoun is used for a particular animal nine times out of ten, except for one occurrence of a logophoric pronoun referring to that same animal, specifically in a context where the animal's thoughts are being reported. Here, the preponderance of non-human pronouns shows the animal is not treated as grammatically [+HUMAN], and so when we observe a logophoric pronoun being used for that same animal, this suggests that [-HUMAN] antecedents are allowed for logophoric pronouns. As I discuss in Sections 5 through 8 , in this paper I focus on this second type of context, using only texts - specifically, children's and young adult books - where the default pronominal form for animals in Finnish is $s e$ 'it.' I use books written for children (and young adults) because they are more likely to have animal protagonists than novels written for adult readers. If we were to look at novels written for adults with animal protagonists, I would expect the same patterns to arise. The animal-referring phenomena reported in this paper should not be construed as a specialized property limited to children's literature.

On the basis of corpus examples, I compare two competing hypotheses about the logophoric system of Finnish. Crucially, I show how looking at reference to animals allows us a clearer view of the logophoric system of standard Finnish and colloquial dialects. This is because reference to animals allows us to better understand the behavior of logophoric hän: unlike reference to humans, which shows register variation in Finnish, the default form for animals does not change across registers and thus offers a clearer view of the hän/se alternation. In addition, investigating whether logophoric hän can be used with animals offers insights into the conceptualization of animals in language. I argue in favor of a unified logophoric system for both colloquial and standard Finnish. The data presented in this paper suggests that use of hän can be triggered in both colloquial and standard Finnish by the referent being the perspectival center, even if it is not [+HUMAN].

The structure of the paper is as follows. In Section 2 I briefly review logophoric pronouns crosslinguistically, and in Section 3 I turn my focus to human-referring logophoric pronouns in Finnish. I first discuss contexts involving reported speech or thought (syntactic embedding under attitude verbs) and then consider logophoric pronouns in unembedded contexts which can be analyzed as Free Indirect Discourse (FID). Section 4 reviews my prior work on the Finnish logophoric system, focusing on human referents, for both standard Finnish and colloquial Finnish. In Section 5, we shift our attention to animals, and address potential concerns about anthropomorphism or personification muddying the waters. Then, using corpus data, I first consider reference to animals both in embedded and main clause contexts (Sections 6-7), and then investigate whether the logophoric pronouns in Finnish need to be interpreted de se or also allow de re reference (Section 8). The results and their implications are discussed in Section 9.

\section{Perspective-sensitivity in pronominal reference to humans}

Some languages have a morphologically distinct class of logophoric pronouns that refers to the 'subject of consciousness', i.e. the person whose speech, thoughts or feelings are being reported (e.g. Hagège 1974, Clements 1975, Sells 1987, Culy 1994). In the words of Clements (1975), logophors refer to “....the individual (other than the speaker) whose speech, thoughts, feelings, or general state of consciousness are reported or reflected in the linguistic context in which the pronoun occurs" (Clements 1975:141). This individual is often referred to as the logophoric center. In recent work, Büring (2005:63) states that: "A logophoric pronoun can be used if it is embedded in a constituent $c$ such that (i) $c$ is embedded, (ii) $c$ denotes a proposition $p$, which 
(iii) can be paraphrased as a mental state or reported utterance of the pronoun's antecedent such that the paraphrase contains a first person pronoun in place of the pronoun."

In languages with lexically distinct logophoric pronouns ${ }^{2}$, these specialized forms occur in the scope of predicates reporting speech, thoughts or mental states (e.g. say, think, dream), ex. (1) from Ewe (Clements 1975, Pearson 2015). The logophoric pronoun yè must be interpreted as referring to the subject of saying, and the embedded clause can be paraphrased with a first-person pronoun.

(1) Kofi be yè dzo. (Ewe, from Pearson 2015:78)

Kofi say LOG leave

'Kofi ${ }_{\mathrm{i}}$ said he ${ }_{\mathrm{i} / \star_{\mathrm{j}}}$ left.' (Kofi said: "I left.")

Typological work has identified an implicational hierarchy of attitude predicates, indicating that if a language uses logophoric pronouns in coreferential configurations under predicates of perception, it also uses logophoric pronouns under verbs of thought (e.g. Culy 1994, Stirling 1993, 1994, Huang 2000). This in turn implies that the language also uses logophoric pronouns under verbs of saying/ communication.

Pearson (2015) notes that "Logophoric pronouns are traditionally defined as elements that (....) are obligatorily construed as referring to the bearer of the attitude, such as the subject of believe or say" (Pearson 2015:77-78), in line with ex. (1). However, it seems that non-logophoric pronouns can also corefer with the attitude holder, at least in some languages. Huang (2000:226, citing Hagège 1974) shows that in Tuburi, either a logophoric or non-logophoric pronoun in the embedded clause can corefer with the subject of 'think' in the main clause. Similarly, Pearson finds that some Ewe informants allow coreference in configurations such as (2), with a non-logophoric pronoun in the embedded clause:

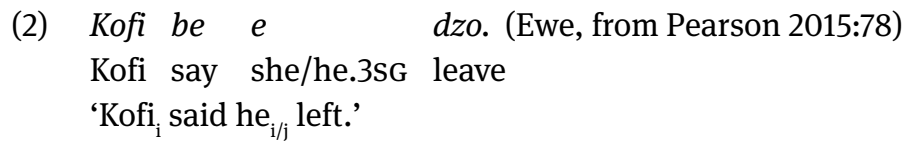

So far, we have been treating logophoricity in a unified way. However, Sells (1987) argues that it can be broken down into three primitives: SOURCE, SELF and PIVOT. He defines the SOURCE as "the one who makes the report (for example, the speaker)," the SELF as "the one whose 'mind' is being reported," and the PIVOT as "the one from whose point of view the report is made," in other words, the deictic center (Sells 1987:455). In recent work, Charnavel \& Zlogar (2015) collapse SOURCE and SELF under 'attitude holder,' a perspectival center involving an intellectual/cognitive perspective, and I follow their approach. As will become clear, for the sake of brevity, in this paper I often use the feature [SELF] when referring to the 'attitude holder'. Thus, my use of the label [SELF] is essentially synonymous with the term 'attitude holder.'

\subsection{Can animals antecede logophoric pronouns?}

So far, in our discussion of prior work on logophoricity, we have been implicitly assuming that the referents whose mental states are being described are human. What about non-human animals? It is clear that humans regard at least some non-human animals as capable of experiencing mental state, which raises the question of whether humans use logophoric pronouns when referring to these animals. Specifically, in contexts where animals are not anthropomorphized and are treated grammatically as [-HUMAN], does the linguistic system still allow us to treat them as entities with the ability to experience mental states and attitudes (i.e., as entities that can be the [SELF]), despite the fact that the ability to experience various mental states (to have a 'rich inner life') is often viewed as a defining part of being human?

2 Some languages do not have lexically distinct logophoric pronouns but use other forms such as reflexive anaphors in logophoric contexts (e.g. Icelandic); see Huang 2000 for further crosslinguistic discussion. 
As we will see, in Finnish the pronoun that has been argued to be logophoric (hän) has the same form as the pronoun that, in Standard Finnish, is the default form for humans but not for animals. This might lead us to expect that animals (unless type-shifted from $e_{\text {animate }}$ to $e_{\text {human }}$, see de Swart \& de Hoop 2018) are excluded from anteceding logophoric pronouns. To the best of my knowledge, there is very limited (if any) discussion of logophoric pronouns being used to refer to animals in prior typological/crosslinguistic work, except for Laitinen's seminal work on Finnish and related languages such as Sami (see Sections 5-7). In particular, prior crosslinguistic work has not systematically investigated whether and in what syntactic (and semantic) configurations logophoric pronouns can be used for sentient thinkers or 'mental state experiencers' that are otherwise grammatically consistently treated as being [-HUMAN] - for example, that are otherwise by default referred to with a non-human pronoun. As I discuss below, to explore this question it is important to look at contexts where the animals are still grammatically of type $e_{\text {animate }}$ and have not been type-shifted to $e h_{\text {uman }}$, using the terminology of de Swart \& de Hoop (2018).

\section{Perspective-sensitivity in pronominal reference to humans: logophoric pronouns in Finnish}

In this section, I review prior work showing that reference to humans in Finnish exhibits a pattern of pronoun alternations that in many ways resembles the logophoric patterns described in Section 2. Some of these logophoric properties were already noted in descriptive work on Finnish as early as 1883 by Setälä, and investigated more recently by Laitinen (2002, 2005, 2009, 2012), Mikkola \& Laitinen (2013), Nau (2006), Priiki (2016, 2017), Kaiser (2018), and others.

\subsection{Finnish pronominal paradigms}

A brief review of the pronominal paradigms of present-day Finnish, in particular the distinction between standard and colloquial Finnish, is necessary as a starting point. Standard Finnish is used in formal writing (e.g. newspapers, textbooks, some fiction) and public/official speech (e.g. television news). However, in casual writing and speech, people use dialects of colloquial Finnish. ${ }^{3}$ These diverge from standard Finnish in terms of their lexicon, morphology, syntax and phonology/phonetics (e.g. Karlsson 1999 and many others). For example, in colloquial Finnish as spoken in the greater Helsinki area, the final [-i] of diphthongs (e.g. ai, oi) is omitted in unstressed syllables (e.g. Standard Finnish sanoi say.PST.3sG becomes sano), and first and second person pronouns are shortened (Standard Finnish minä 'I,' sinä 'you' become mä, sä). Colloquial Finnish has a number of regional variants, but the logophoric patterns discussed in this paper can occur in the majority of dialects. Generally speaking, Finnish speakers are fluent both in standard Finnish and at least one dialect of colloquial Finnish.

One of the most striking asymmetries between standard Finnish and many dialects involves the pronouns used for human referents on the one hand, and animals and inanimates on the other hand. Present-day standard Finnish makes a clear distinction between humans and non-humans: the genderneutral personal pronoun hän 'she/he' (ex.3a' and 3a') is used for human referents (e.g. the neighbor),

\footnotetext{
3 It is worth noting that 'standard Finnish' and 'colloquial Finnish' should not simply be equated with 'written Finnish' and 'spoken Finnish'. For example, informal/casual written communication - such as internet discussion boards - often uses colloquial Finnish. The reader should also be warned that, for purposes of expository clarity, this paper is written as if the two registers are fully distinct - but given that register variation is encoded morphologically, lexically, phonologically and in other ways, there can be gradations and hybrids that may resemble colloquial Finnish on one level and standard Finnish on another level. Importantly, this is not a problem for the key claims of the present paper, for two main reasons. First, in the case of reference to humans, I focus on source texts where the default pronominal form is known or can be clearly identified, and thus provides an indication of whether the source text patterns like standard Finnish or colloquial Finnish in terms of its default pronoun use. Second, in the case of reference to animals, we can sidestep complications stemming from register variation, because the default form for referring to animals does not change across registers.
} 
whereas non-human animals and inanimates (e.g. the cat) are referred to with se 'it' (ex.3a' and 3a"). ${ }^{4}$ This distinction largely mirrors 'she/he' vs. 'it' in English. Laitinen $(2009,2012)$ notes that this human vs. nonhuman division in the use of se and hän was established in written (standard) Finnish by the early 1900s.

(3) [Standard Finnish]

a) Naapuri-ni $i_{i} \quad$ hoita-a kissa-a-ni, kun ole-n matko-i-lla. Neighbor.NOM-1Px ${ }^{5}$ cares.for-3SG cat-PAR-1Px, when be-1SG trip-PL-ADESS 'My neighbor ${ }_{i}$ takes care of my cat ${ }_{i}$ when I am traveling.'

a') ...Onneksi se ei enää pelk $\ddot{a}$-ä hän-tä ${ }_{i}$. Fortunately it.NOM neg.3sg anymore fear-3sG she/he-PAR 'Fortunately it ${ }_{\mathrm{j}}$ no longer fears him $\mathrm{i}_{\mathrm{i}} /$ her $_{\mathrm{i}}$ '

a”)...Onneksi hän $n_{i} \quad$ ei enää pelkä-ä si-täa Fortunately she/he.Nom neg.3sg anymore fear-3sg it-PAR 'Fortunately she $_{\mathrm{i}} / \mathrm{he}_{\mathrm{i}}$ no longer fears it,

The anaphoric paradigms in dialects of colloquial Finnish are quite different. In the majority of dialects, se is the default form for both human and non-human referents, with the exception of some south-eastern and south-western dialects (e.g. Vilppula 1989). ${ }^{6}$ Indeed, Kallio (1978:65, cited by Suonperä 2012) states that the use of se when referring to human referents is so frequent in colloquial language, excepting only the most formal settings, that no specific evidence is needed to support this observation. Thus, in colloquial Finnish, se can refer to humans, non-human animals (ex. 3b) as well as inanimates. This renders the pronouns in the second clause of ex. (3b) more ambiguous than those in (3a'-3a"): at least in principle, it could be that the cat no longer fears the neighbor or the neighbor no longer fears the cat.

(3) [Colloquial Finnish]

b) Mun naapuri ${ }_{i}$ hoitaa mun kissa- $a_{\rho}$, ku mä o-on matkoilla. My neighbor.Nom cares.for-3sg my cat-PAR, when I.NOM be-1sG trip-PL-ADESS 'My neighbor ${ }_{i}$ takes care of my cat ${ }_{j}$ when I am traveling.'

b') Onneks $\quad s e_{i / j} \quad$ ei enää pelkä-ä si-tä $\ddot{j}_{j / i^{\circ}}$ Fortunately it.NOM neg.3SG anymore fear-3SG it-PAR 'Fortunately $\{\text { it / she } / \text { he }\}_{\mathrm{i} / \mathrm{j}}$ no longer fears $\{\text { it } / \text { him } / \text { her }\}_{\mathrm{j} / \mathrm{i}}$ '

In sum, there is a tension between the default forms used in the pronominal systems of standard Finnish and colloquial Finnish: whereas standard Finnish uses hän 'she/he' for humans and se 'it' for animals (and inanimates), many colloquial dialects use se 'it' as the default for both. In the following sections, I turn to the non-default pronominal options and the referential properties and contexts that motivate their use.

4 For ease of presentation, I translate se as 'it'. However, se is often regarded as a hybrid that has properties of both anaphoric and demonstrative pronouns (e.g. Larjavaara 1990). In contrast to the proximal demonstrative tämä 'this' and the distal demonstrative tuo 'that', se has been analyzed as placing the referent in the addressee's sphere and being unmarked/neutral with respect to the speaker (see Laury 2005). Se can also occur on its own or as a prenominal modifier, in which case its meaning is similar to English 'the' or 'that', e.g. se kissa 'the cat/that cat' (see Laury 1997). Se is also used for discourse deixis (Hakulinen \& Karlsson 1989:316). Furthermore, even in standard Finnish se can refer to humans in certain contexts, e.g. in otherwise 'headless' relative clauses (ex.i).

(i) Pekka on se, jo-ta etsi-t.

Pekka.Nom be.3SG it.NOM, who-PAR look.for-2SG

'Pekka is the one you are looking for.' (Sulkala \& Karjalainen 1992:120)

5 In Standard Finnish, possession is marked with possessive suffixes, abbreviated Px, that agree with the possessor in person and, in some persons, also in number. Genitive pronouns are used if the possessor does not locally c-command the possessive construction. As will become clear later on, possessive constructions without overt possessive pronouns do not distinguish between humans and animals, between hän and se, as both use the same 3rd person possessive suffix. Colloquial Finnish often only uses genitive pronouns, without possessive suffixes (see e.g. Hakulinen et al. 2005).

6 As regards reference to animals, see also Laitinen (2009:120-121) on dialectal variation and non-logophoric uses of hän in some dialects. I focus here on colloquial dialects where the default form (for humans and animals) is se, as my focus is on the question what motivates the use of $h \ddot{n}$. 


\subsection{Logophoric pronouns in reported speech/thought contexts in Finnish}

In addition to the default form se 'it', many colloquial dialects also use the standard Finnish human pronoun hän 'she/he' in a specific context - namely in embedded clauses that convey reported speech/thought (e.g. Setälä 1883, Kuiri 1984, Ylikahri 1996, Laitinen 2002, 2009, see also Priiki 2016, 2017, Kaiser 2008, 2018, inter alia). Specifically, Laitinen (2002) notes that the pronoun hän "appears in reported speech or thought and is coreferential with the subject of the speech act or mental verb used to introduce it" (Laitinen 2002:327). This sounds very similar to what we saw above with the logophoric pronouns in Ewe and other languages (see also Nau 2006 on the links between Finnish hän and logophoric pronouns in African languages). For example, in (4a), hän 'she/he' is used in a clause embedded under the verb 'say' and is coreferential with the matrix subject (realized with default se 'it'): hän refers to the person whose speech is being reported. In the English translations, I will typically use she/he to indicate an occurrence of hän in the Finnish original, and English it to indicate an occurrence of $s e$ in the Finnish original. I will also use subscripts to indicate coreference.

The same pattern can be seen in (4b). These examples are all from colloquial Finnish (signaled by morphological patterns and other grammatical cues, as well as use of se as the default pronoun for humans). See Kaiser (2018) for further discussion; these examples are from Kaiser (2018:83).

(4) a) [Context: talking about good fishing spots]

Kundi $_{\mathrm{i}}$ luule-e omista-va-nsa se-n paika-n, Guy.NOM think-3sG own-PTCP-3PX the-ACC place-ACC,

vaikka mä ol-i-n aamu-lla

although I.NOM be-PST-1sG morning-ADESS

jo tunti-a ennen si-tä $\ddot{\mathrm{a}}_{\mathrm{i}}$ si-llä paika-lla.

already hour-PAR before it-PAR that-ADESS place-ADESS

$\boldsymbol{S e}_{\mathrm{i}}$ sano, että hän $\boldsymbol{i}_{\mathrm{i}}$ on tän paikan alun perin löytänyt.

It.NOM say.PST.3sG that he.NOM be.3sG this-ACC place-ACC originally find-PTCP

(www.jippii.fi/jsp/forum/thread.jsp?b=kalastus\&t=570)

'The guy ${ }_{\mathrm{i}}$ thinks he owns the place, although I was already there in the morning an hour before $\mathbf{i t}_{\mathrm{i}}$. $\mathbf{I t}_{\mathbf{i}}$ said that he $\mathbf{i}_{\mathbf{i}}$ had originally found this place.'

b) [Context: talking about good places to use a metal detector to find jewelry]

Kerro-i-n kouluttaja-lle, että on tosi huono-ja ranto-ja

Tell-PST-1sG trainer-ALL, that be.3sg really bad-PL.PAR beach-PL.PAR

kun on vaan yksi kulta löytynyt

when be.3sG only one.Nom gold.NOM find-PTCP

ni $\mathrm{se}_{\mathrm{i}}$ sano, että hän ${ }_{\mathrm{i}}$ tietä-ä yhde-n hyvä-n ranna-n

so it.NOM say.PST.3sg that he.NOM know-3sg one-ACC good-ACC beach-ACC

mi-ssä käy usein rikka-i-ta

where-INESS go.3SG often rich-PL-PAR

(http://www.aarremaanalla.com/foorumi/viewtopic.php?t=6722, May 2012)

'I told the trainer ${ }_{i}$ that these are really bad beaches since only one gold object has been found so it $_{\mathbf{i}}$ said that $\mathbf{h e}_{\mathbf{i}}$ knows a good beach where rich people often go'

Given the striking parallels between this use and the examples considered in Section 2, Laitinen (2002, 209, 2012) calls this a logophoric use, and I follow her in using this term (see also Nau 2006, Priiki 2016, 2017). The use of hän in these contexts is not required, however. Hakulinen et al. (2005) present the example in (5) to show that se can be embedded under a verb of saying and can still be coreferential with the subject of saying (see Hakulinen et al. 2005:1409 for a similar example with a verb of thinking). Use of $s e$ in the Finnish is indicated in the English translation with it. This echoes Pearson's (2015) observation that, at least for some speakers of Ewe, the use of a logophoric pronoun is not required in these kinds of contexts. 
(5) $\quad \mathbf{S e}_{\mathrm{i}}$ katsoi vettä ja siltaa ja sanoi että $\mathbf{s e}_{\mathrm{i}}$ yöpyy usein tässä hotellissa työreissulla.

(Hakulinen et al. 2005, p.1409, example from a novel using 'se' as default)

'It looked at the water and at the bridge and said it $_{\mathrm{i}}$ often stays in this hotel on business trips.'

The kinds of attitude predicates under which logophoric hän occurs in colloquial Finnish closely resemble those predicates that have been associated with logophoric pronoun use in West African languages (Section 2) - further suggesting that this use of $h a ̈ n$ is logophoric. In addition to speech act predicates, other predicates are also possible (e.g. ajatteli, 'thought' in ex. (6a,b), see also Laitinen 2005 for examples of direct perception, Priiki 2016, 2017 for quantitative analyses, Setälä 1883 for discussion of other contexts). The default pronoun for humans is se (as can be seen in the examples), but hän can be used in the embedded clause under a mental state predicate when referring to the person whose thoughts/speech/mental state is being expressed.

(6) Thought predicates

a) [Context: Interview with a World War 2 pilot, talking about his experiences]

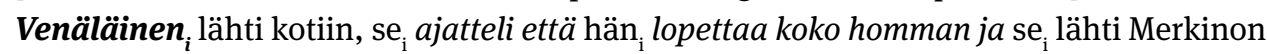
kentälle (http://www.virtualpilots.fi/en/hist/WW2History-ViljoLehtinen.html)

'The Russian ${ }_{\mathbf{i}}$ left to go home, $\mathbf{i t}_{\mathbf{i}}$ thought that $\mathbf{h e}_{\mathbf{i}}$ will stop the whole thing and $\mathbf{i t}_{\mathbf{i}}$ left to go to Merkino airfield'

b) [Context: The speaker has a colleague hoping to renovate his/her patio but in need of a work crew] ${ }^{7}$ Niin ne vaan aamukahvilla tuolla puhu ku se $\boldsymbol{e}_{\mathrm{i}}$ mietti, että hän $\boldsymbol{n}_{\mathrm{i}}$ ei saa aikaseksi, ku hänellä ${ }_{\mathrm{i}}$ ei oo

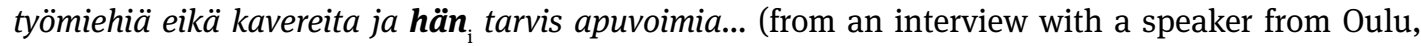
reported by linatti 2015:38)

'so they were talking over morning coffee when $\mathbf{i t}_{\mathbf{i}}$ was pondering that $\mathbf{s h e} / \mathbf{h e}_{\mathbf{i}}$ won't be able to get (it) done, as she/he $\mathbf{~}_{\mathbf{i}}$ has no workmen or friends and she/he $\mathbf{e}_{\mathbf{i}}$ needs help'

In sum, the data presented in this section suggests that hän signals reference to the attitude holder. As I mentioned in Section 2, I will often simply use the label SELF, which I intend to mean attitude holder: the person whose speech, thoughts or attitudes are being conveyed. Further, the examples in this section show that the use of hän is not obligatory when referring to the attitude holder/SELF: Reference to SELF can also be accomplished with se, the form that is the default in colloquial Finnish.

\subsection{Perspective-sensitivity in main clauses: free indirect discourse and reference to humans}

Based on the data so far, viewing hän as a logophoric pronoun that occurs embedded under attitude verbs provides a promising account of the se/hän alternation in colloquial Finnish. However, what about contexts such as ex. (7a,b) (Kaiser (2018:76)? In (7a), Tiina is referred to with hän, but in (7b) she is referred to with se. In both cases, the pronoun is the subject of a matrix clause and is not embedded under a mental state or speech verb. These are both examples from a novel written in standard Finnish, where hän is the default for humans and se for non-human animals and inanimates.

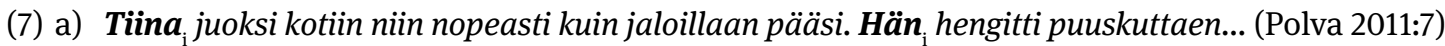
'Tiina ${ }_{\mathrm{i}}$ ran home as fast as her legs would carry her. She ${ }_{\mathrm{i}}$ was out of breath...'

b) Sekasotkua $\mathrm{se}_{\mathrm{i}}$ joka tapauksessa oli saanut aikaan, kuten tavallisesti. (Polva 2011:29) 'In any case, $\mathbf{i t}_{\mathbf{i}}$ had made a mess of things, as usual.'

7 The thought predicate miettiä 'to ponder' is used here, but the context strongly implies that the person doing the pondering also articulated their thoughts aloud to the person they were having coffee with. 
In standard Finnish, what could be triggering use of se in some contexts and hän in others, in main clause contexts with no attitude verbs? It's worth acknowledging right away that the use of se to refer to a human in standard Finnish (ex.7b) may seem unexpected, in light of the preceding discussion. Pre-empting the subsequent sections somewhat, the claim is that in (7b) we are dealing with a case of Free Indirect Discourse (FID) and that se 'it', when used inside FID, can be used even in standard Finnish for the NONSELF, i.e. a referent other than the attitude-holder. (In this case, the attitude-holder is Tiina's mother, who is thinking about her daughter.)

Free Indirect Discourse (FID) is a means of conveying a character's speech or thoughts without using a direct quote or an embedding speech or mental state verb. In direct speech, e.g. Peter said, 'I will go home tomorrow', first-person pronouns are used to refer to the character who is speaking. In indirect speech/ reported speech, e.g. Peter ${ }_{i}$ said that he ${ }_{i}$ would go home tomorrow, the speaker/character is referred to with a third person pronoun. In free indirect discourse, there is no matrix clause with a verb of speaking/thinking, and instead the text represents a character's speech or thoughts directly. A third-person pronoun can be used to refer to the SELF: Peter was tired of sleeping on Tim's couch. How could anyone sleep on that old thing, with a mattress as hard as a brick? He ${ }_{i}$ would go home tomorrow. No one was going to make him change his mind about that.

More specifically, in Kaiser (2018), I build on prior work and analyze examples like (10b) as involving Free Indirect Discourse (FID). In that work, I propose a unified account of the hän/se alternation in colloquial Finnish (reported speech/thought) and standard Finnish (Free Indirect Discourse) for reference to humans. I briefly present the relevant background and data in this section, and then summarize and extend my prior proposal in Section 4, as it is relevant for my claims about animal reference patterns in the subsequent sections.

As Saukkonen (1967) notes, in Finnish hän is used in FID to refer to the speaker/thinker/attitude holder, who I refer to as the SELF. More specifically, my corpus data show the following basic patterns: (i) inside free indirect discourse, the SELF (the person whose mental state or speech is being conveyed) is referred to with hän 'she/he' and (ii) se 'it', when used inside FID, refers to the NON-SELF, i.e. a referent other than the attitude-holder (see also Saukkonen 1967, Hakulinen 1988, Rivinoja 2006, Kaiser 2008, 2018).

This pattern is exemplified in ex. (8) from a novel by Joensuu (1983). In this extract, one of the characters, Mikael, is coming downstairs from his bedroom and listening to find out who is home. Mikael - the SELF, from whose perspective we see and hear things - is referred to with hän 'he', and his mother with se 'it'. Unlike the reported speech examples in the preceding sections where se was in a matrix clause with a speech/thought verb and hän was in the embedded clause, se and hän both occur in matrix clauses (ex.8).

(8) Mikael $_{\mathrm{i}}$ tuli portaat alas niin hiljaa kuin osasi.

Eteisessä oli hämärää. Hän seisoi aloillaan, pidätti henkeä ja kuunteli.

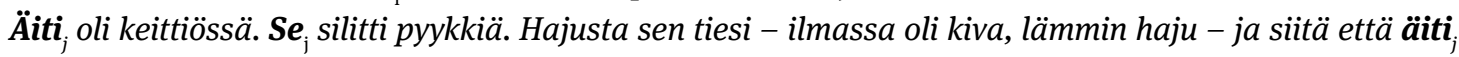
hyräili hiljaa. (Joensuu 1983:31)

'Mikael ${ }_{i}$ came downstairs as quietly as possible.

The foyer was dark. $\mathbf{H e}_{\mathbf{i}}$ stood still, held his breath and listened.

Mother ${ }_{j}$ was in the kitchen. It ${ }_{j}$ was ironing. One could tell from the smell - there was a nice, warm smell in the air - and from mother,'s quiet humming.'

Use of se in free indirect discourse for the NON-SELF referent is not obligatory; hän can also be used (see Rouhiainen 2000). In (9), which comes from a longer extract of the Finnish translation of Women in Love by D.H. Lawrence discussed by Rouhiainen (2000:118), we hear the thoughts of one of the protagonists, Gudrun, about her lover Gerald, and hän refers to the NON-SELF referent Gerald. The larger context of this extract makes it clear that we are hearing Gudrun's thoughts, that she is the SELF.

8 The translation of se as 'it' in ex.8, when referring to a human, may sound jarring to English speakers. As mentioned above, I translate Finnish se as 'it' in English to distinguish it from hän, which I translate as 'she/he' in English. In colloquial Finnish, se can be used for human referents without any rude or derogratory undertones. 
(9) Geraldin ${ }_{\mathrm{i}}$ pitäisi päästä sellaiseen asemaan, missä hän $\mathrm{i}_{\mathrm{i}}$ tahdonvoimallaan ja ylivertaisella käytänöllisellä älyllään voisi ratkaista nykyajan teollisuuden pulmat. (Lawrence 1980:541) 'Gerald $\mathbf{i}_{\mathbf{i}}$ should achieve a position where $\mathbf{h e}_{\mathbf{i}}$, with his force of will and supreme practical intelligence, would be able to solve the problems of modern industry.'

In sum, we see that in FID contexts, hän can be used to refer to SELF (8) or to NON-SELF (9) and se is used to refer to NON-SELF (7b) but not to SELF. It is worth noting that these examples are from standard Finnish, where hän is the default for human antecedents.

\subsection{Logophoric pronouns and Free Indirect Discourse in other languages}

In the preceding sections I discussed the idea, not specific to Finnish, that free indirect discourse and embedding under attitude predicates resemble each other but differ in the scope of the logophoric/ perspectival domain (e.g. Kaiser 2018, see also Section 4). This view receives further support from observations made in prior work about seemingly 'unexpected' uses of morphologically distinct logophoric pronouns (though the phenomenon is not normally described in these prior papers as involving FID).

For example, Pearson (2015) notes that in Ewe, the logophoric pronoun yè is normally ungrammatical in simple matrix clauses, in contrast to the regular pronoun $e$ (ex.10) but, as already noted by Clements (1975) and also discussed by Pearson, yè can occur in a matrix clause when preceded by a sentence containing an attitude predicate, "in which it case it [yè, EK] must denote the attitude holder associated with the predicate in this earlier sentence" (Pearson 2015:96). This is shown in (11).

(10) * Yè / ok e dzo.

LOG / she/he.3sg leave

'She/he left.'

(11) Kofi koudrin be yè bidzi. Marie zu yè. Kofi dream COMPL LOG angry. Mary insult LOG.

'Kofi ${ }_{i}$ dreamed that he ${ }_{i}$ was angry. Mary insulted him ${ }_{i}$ '

According to Pearson (2015:96), her native speaker consultants draw the inference that the insult took place in the dream or that this is a report of Kofi describing the dream to Mary - in other words, they interpret yè as occurring in the scope of an attitude. This fits with Clements's (1975:17) observation that Ewe logophoric pronouns can refer to antecedents in preceding sentences, in situations where the point-of-view has shifted from the narrator to another individual. Related data from Tamil, for the anaphor taan, is discussed by Sundaresan (2012:41). When taan occurs in matrix subject position, its antecedent is "has a psychological/ mental attitude with respect to a proposition in which the anaphor is a participant" (Sundaresan 2012: 45).

In sum, from a crosslinguistic perspective, it appears that logophoric pronouns can be used (i) inside a 'perspectival domain,' e.g. when embedded under explicit perspective-signalling verbs (e.g. verbs of saying and verbs of mental state) or (ii) in cross-sentential contexts when inside the domain of free indirect discourse.

\section{Kaiser's (2018) analysis for human reference}

When it comes to a human referent conceptualized as the SELF, the speaker/thinker, in Sections 3.2 and 3.3 we saw that (i) in colloquial Finnish, the default se can refer to NON-SELF or SELF, whereas hän is used to refer to SELF. On the other hand, (ii) in standard Finnish, the default hän can refer to NON-SELF or SELF, whereas se is used for NON-SELF human referents. In Kaiser (2018) I argue that we can derive these patterns from the register-based defaults when combined with the association between hän and the attitude 
holder/SELF. I also argue that there is no need to posit an additional association between se and NON-SELF. However, in the case of human reference, the claim that hän potentially has a logophoric interpretation (in both standard and colloquial Finnish) is complicated by the fact that hän is also the register default for humans in standard Finnish. Before considering this complication in more detail, let us consider the properties of the proposed system in more depth, especially as they relate to the [+/- HUMAN] property.

From a speaker-oriented production perspective, in standard Finnish, [+HUMAN] reference is accomplished with hän, and [-HUMAN] reference with se, while in colloquial Finnish, both [+/- HUMAN] reference is done with se. In addition, to capture the data in Sections 3.2 and 3.3, Kaiser (2018) hypothesized that reference to logophoric SELF referents is accomplished with hän in both standard and colloquial Finnish. This account is summarized in (12) under the label Hypothesis 1.

(12) Hypothesis 1 (logophoric pronoun is the same in both registers)

(a) Register-based default mapping: Standard Finnish: $[+$ HUMAN $]=>$ hän $\quad[-$ HUMAN $] \Rightarrow$ se Colloquial Finnish: [+/- HUMAN] $\Rightarrow$ se

(b) Perspective-based mapping: [logophoric/SELF] => hän

Crucially, this specific association between hän and SELF must be able to take priority over registerdependent default mappings. This is needed to explain the use of hän for [+HUMAN] SELF referents in colloquial Finnish (Section 3.2), since otherwise only se would be used. However, the priority cannot be absolute, since - as we saw above - whatever is the default form in a register can also be used for SELF referents. In the case of Standard Finnish, with human referents, we face the challenge of hän being the register default for humans. Thus, from a morphological perspective, using hän to refer to the SELF is vacuous in standard Finnish. Reference to animals offers a situation where this issue of vacuity is not present.

In general terms, the patterns discussed by Kaiser (2018) - at least in the case of colloquial Finnish can be captured with Horn (1984)'s division of pragmatic labor (13). For colloquial Finnish, the idea is that, from the hearer's perspective, the speaker's use of hän (the more marked option) - in a context where se (the unmarked option) is also available - signals a marked message to the hearer, namely that hän refers to the SELF.

(13) Division of pragmatic labor: "The use of a marked (relatively complex and/or prolix) expression when a corresponding unmarked (simpler, less 'effortful') alternative expression is available tends to be interpreted as conveying a marked message (one which the unmarked alternative would not or could not have conveyed) (Horn 1984:22)

With human reference in standard Finnish, however, the situation is more complex due to hän being both the marked option (SELF referring) and the unmarked/default option. As will become clear below, in the current paper I show that looking at reference to animals crucially sidesteps this complication and thus allows us to assess the referential properties of the pronouns more directly.

Alternatively (and relatedly), by focusing on the production side and how the speaker chooses which form to use, one could capture the Finnish patterns by means of Heim's Maximize Presupposition principle: "Make your contribution presuppose as much as possible" (Heim 1991:28). Thus, if there are two (or more) expressions that mean the same thing, the speaker should use the one with more presuppositions. In other words, a speaker should use the expression that is associated with the strongest presupposition compatible with the speaker's knowledge. Chemla (2008:142) formulates Maximize Presupposition as follows: "Among a set of alternatives, use the felicitous sentence with the strongest presupposition."

In the case of pronouns, the standard view is that gender, person and number features are presuppositional (e.g. Cooper 1983, Heim \& Kratzer 1998, but see also Yanovich 2012 and Sudo 2012). Since Finnish does not mark gender on pronouns, let us put aside gender features for now. In Heim's system (1991), third person pronouns only carry the presupposition of 'non-participant' (i.e., that the referent is 
not the speaker or the addressee). From a semantic perspective, they are less marked than first or second person pronouns - indeed, third-person pronouns have been argued to be featurally unmarked (e.g. Sauerland 2008). Thus, in colloquial Finnish, se is presumably featurally unmarked (indeed, it is arguably even less marked than English she/he, because in colloquial Finnish se can refer to humans, non-humans and inanimate things). In contrast, $h a ̈ n$ in colloquial Finnish refers to a SELF referent: although it is a third person pronoun, it is clearly not featurally unmarked. Following prior work on gender, number and person, let us assume that logophoric reference is also presuppositional. This yields a situation where, in a SELFreferring context, a sentence with hän is felicitous and presupposes more than a sentence with se, and so Maximize Presupposition states that hän is the form the speaker should use.

Thus, when a Finnish speaker utters a colloquial Finnish sentence where they refer to a third person human referent who is the SELF, they could use se (as a register default) or hän (as a SELF referring pronoun), but due to Maximize Presupposition we expect them to prefer hän. So, we can use Maximize Presupposition to explain why the specific association between hän and SELF is able to trump the register default of colloquial Finnish - though it is less clear how this approach could capture the fact that in colloquial Finnish, the register default se can nevertheless also occur in logophoric contexts (see footnote 10 for discussion).

Furthermore, just as with Horn's division of pragmatic labor, things become more complex when we turn to Standard Finnish. ${ }^{9}$ When a Finnish speaker produces a standard Finnish sentence and they refer to a third person human referent who is the SELF, both the register-based default and perspectivebased mapping point to hän: in standard Finnish the default form for humans and the form that has been analyzed as logophoric look the same. Thus, the claim that $h a ̈ n$ can be a logophoric pronoun is less evident in standard Finnish than in colloquial Finnish, because there is no se/hän form alternation for human referents. However, in Kaiser (2018) I discuss several examples involving the interpretation of subjective adjectives indicating that hän has logophoric properties in Standard Finnish. ${ }^{10}$ Nevertheless, the fact that the default human pronoun looks the same as (what I claim to be) the logophoric pronoun makes the patterns harder to detect than in colloquial Finnish. One might thus wonder about the validity of the claim that $h \ddot{n}$ is logophoric in both colloquial and standard Finnish.

In fact, an alternative interpretation of the data in Sections 3.2 and 3.3 is to say that the two registers have different logophoric systems, as illustrated in (12') under the label Hypothesis 2 . Hypothesis 2 states that, in contrast to colloquial Finnish where $s e$ is the default form for humans and hän is logophoric/refers to the SELF (12'b), in standard Finnish hän is the default form for humans (unmarked for logophoricity) and $s e$ is anti-logophoric and cannot refer to the SELF (12'a). Under this view, colloquial Finnish has a logophoric pronoun (hän) and standard Finnish has an anti-logophoric pronoun (se), rather than both registers having an association between hän and logophoricity.

(12') Hypothesis 2 (logophoric system is different in the two registers)

(a) Standard Finnish: [+HUMAN] $\Rightarrow$ hän

$$
\begin{aligned}
& {[\text {-HUMAN] }=>\text { se }} \\
& {[\text { anti-logophoric/-SELF] } \Rightarrow>\text { se }}
\end{aligned}
$$

\footnotetext{
9 I present Maximize Presupposition and Horn's division of pragmatic labor as two means of capturing some aspects of the Finnish pronoun patterns - the aim of the present paper is not to argue for one over the other. Horn's approach is more oriented towards a comprehender's interpretation of pronouns whereas Maximize Presupposition is more oriented towards a speaker's choice of which form to use. Crucially, both run into complications when trying to capture the patterns we observe with human reference in Standard Finnish, due to the register default for [+HUMAN] referents and the logophoric form being the same form. 10 A question that is not yet resolved that I leave for future work concerns the felicity of using se in SELF-referring contexts in colloquial Finnish. As mentioned above, se is not ungrammatical or strongly infelicitous in such contexts, though it is clearly less informative than hän. Depending on how we construe Maximize Presupposition, we may end up incorrectly predicting use of $s e$ to be infelicitous in these contexts. Thus, what may be needed is a defeasible form of Maximize Presupposition, which is in fact in line with Heim's suggestion that Maximize Presupposition could be a defeasible conversational maxim in the sense of Grice (1975) - namely a behavioral tendency motivated by broad considerations about cooperativeness in communication (see e.g. Lauer 2016 for related discussion).
} 
(b) Colloquial Finnish: [+/- HUMAN] $\Rightarrow$ se

[logophoric/SELF] => hän

To evaluate these competing hypotheses - Hypothesis 1: hän is logophoric in both registers in Finnish and Hypothesis 2: the two registers have different logophoric pronoun systems - we can look at reference to animals, because the default form for animals in both registers is se. Thus, looking at animal reference allows us to test more directly whether hän is logophoric (used to refer to the SELF) in both standard Finnish and colloquial Finnish. Let us consider the predictions for animal referents in more depth.

Given that the default form for animals in both registers is se, any occurrences of hän with an animal, [-HUMAN] antecedent can be used to test the possibility that hän is logophoric: these animal-referring hän occurences cannot be attributed to register defaults. Crucially, according to Hypothesis 1, we predict that if animals can be conceptualized as SELF - hän should be used for animals that are SELF referents. This is because the association we have posited between hän and [SELF] does not make reference to [+/- HUMAN]. Thus, we predict that use of hän for [-HUMAN] animals that are [SELF] should be possible even in a context where the default form for [-HUMAN] animals is se. In other words, in both standard and colloquial Finnish, in a context where the default pronoun used for a particular animal is se, the prediction is that hän can be used to refer to that same animal only in contexts where the animal is the SELF. Note that this is crucially not the same prediction as personification / anthropomorphism, as will be discussed in the next section.

In contrast, Hypothesis 2 predicts a stark asymmetry in terms of what pronouns can be used for animals in standard vs. colloquial Finnish. Specifically, it predicts that in colloquial Finnish, hän can be used for [-HUMAN] animals if they are [SELF] - similar to Hypothesis 1. Crucially, Hypothesis 2 also predicts that in standard Finnish, hän cannot be used for [-HUMAN] animals, even if they are [SELF], because under this view standard Finnish only has an antilogophoric pronoun (se).

In sum, prior work on logophoric pronouns in Finnish has mostly focused on reference to humans (with the exception of Laitinen's work, which I discuss below), but the issue is complicated by the fact that the default human-referring pronoun in standard Finnish is the same as the form that is hypothesized to be logophoric. In order to better assess the logophoric pronoun systems of standard and colloquial Finnish (and to distinguish between Hypotheses 1 and 2 above), we can turn to reference to animals, which sidesteps the 'same form' problem that we encounter with human reference.

\section{Reference to animals}

Unlike reference to humans, which shows register variation in Finnish, the default form for referring to animals does not change across registers and thus offers a clearer view of the hän/se alternation. Since se is the default form for animals, then as long as we eliminate texts where animals are treated grammatically as [+HUMAN] (or, borrowing terms from de Swart de Hoop 2018, typeshifted from $e_{\text {animate }}$ to $e_{\text {human }}$ ), any occurrences of $h a ̈ n$ with animals can safely be regarded as logophoric. This allows us to get a clearer picture of the behavior of logophoric hän and to assess whether Hypothesis 1 or 2, as described above, better describes the Finnish logophoric system. In addition, investigating whether logophoric hän can be used to refer to animals also offers a way to gain insights into the conceptualization of animals in language. Specifically, we ask whether referents that are treated by the linguistic system as [-HUMAN, +ANIMATE] can also be conceptualized as the attitude holder/SELF, as diagnosed by the use of logophoric pronouns, or whether the use of logophoric pronouns is reserved only for SELF referents that are also [+HUMAN].

Before continuing, we need to discuss the distinction between (i) situations involving anthropomorphism - specifically, the treatment of animals linguistically (and otherwise) as if they were human - and (ii) situations where an animal is clearly an animal in terms of its categorical features (i.e., [-HUMAN]) but is nevertheless the attitude holder/SELF. 


\subsection{Dissociating anthropomorphic uses from logophoric uses}

When investigating reference to animals, one concern that immediately comes to mind has to do with personification and anthropomorphism. In English, for example, people can refer to their pets with 'he' and 'she' instead of 'it' (see Guzmán-González 2013, Gardelle 2013, 2012, Sealey \& Oakley 2013, Teterina 2012). If our aim is to sidestep the complications that arise with human referents due to the register default in standard Finnish (hän) being the same as the logophoric pronoun by investigating reference to animals, we want to avoid contexts where animal referents also have hän as their default form. In this section, I argue that in Finnish, use of hän for animals is dissociable from anthropomorphism, and show that we can avoid complications by focusing on texts where animals clearly have se as the default form.

Let us start by briefly reviewing the notion of anthropomorphism. It is well-known that humans have a tendency to attribute humanlike attributes to nonhuman things - in other words, to anthropomorphize ${ }^{11}$ (see e.g. Waytz et al. 2010 for recent discussion). As noted by Turner, "We are people. We know a lot about ourselves. And we often make sense of other things by viewing them as people too" (Turner 1987:21, cited by Guthrie 1993:129). This attribution of human characteristics may involve (i) physical features that are characteristic of humans (e.g. seeing faces in clouds) and (ii) human mental attributes (e.g. attributing intentions or emotions to nonhuman things, such as computers). The presence of humanlike faces or movements usually implies the presence of humanlike mental attributes. As noted by Waytz et al (2010), anthropomorphism is not just animism (defined as attributing life to a nonliving thing), but rather involves the attribution of distinctly human characteristics - especially mental capacities such as intentions and emotions - to nonhuman things.

One might thus be concerned that looking at reference to animals does not offer a means of testing whether [-HUMAN] referents can nevertheless be antecedents of logophoric pronouns and the 'human-associated' hän form in particular, if speakers/writers anthropomorphize animals and in particular if they treat them linguistically as [+HUMAN]. However, I argue that this concern is misplaced, for two main reasons: First, as illustrated by examples (14-15), in Finnish one can describe animals engaging in human-like activities and exhibiting human-like mental attributes and felicitously use the pronoun se. The novels that I analyzed (children's books and young adult fiction, listed in (16) below, written in standard Finnish) contain many contexts similar to those in ex. (14-15), showing animals acting like humans but nevertheless referred to with se (indicated in the English translations as it). ${ }^{12}$ Thus, if we regard animals that think, plan, prepare speeches in their head while showering, etc. as being anthropomorphized, then we can conclude that in Finnish, anthropomorphizing animals is not sufficient to trigger use of $h a ̈ n \cdot{ }^{13}$

(14) 'Se' used for Bernie the dog with verbs of mental state

Bernie $_{\mathrm{i}}$ meni suihkuhuoneeseen ja väänsi veden täysillä valumaan. Mielessään $\boldsymbol{s e}_{\mathrm{i}}$ jo suunnitteli puhettaan koko koirayleisön edessä. S $\boldsymbol{e}_{\mathrm{i}}$ mietti myös millainen tarinan loppu voisi olla... (Kukkanen, p.50)

11 Anthropomorphism is sometimes regarded as a synonym for personification, but the term personification is also used in a more specific way: Personification is often regarded as a specific kind of literary device (e.g. Guthrie 1993:124), specifically for situations where inanimate objects and especially abstracts (e.g. liberty, truth) are represented in human form, as is often done in poetry or art.

12 The aim of these examples is to show that in standard Finnish, use of se is not precluded with verbs that normally select for human subjects. I.e., an animal engaged in human-like activities can be referred to with se. Thus, a claim that ' $h \ddot{n}$ must be used when the animal is anthropomorphized' is not correct. Note also that the occurrence of se in these examples is (i) not in the scope of Free Indirect Discourse, and is (ii) not embedded under a verb of communication or thought. Thus, these contexts are distinct from the kinds of contexts I discussed in 3.2 and 3.3. As we will see later on, different patterns emerge when an animal is referred to in the scope of FID or a verb of communication/thought.

13 From the perspective of de Swart \& de Hoop's (2018) work on animacy type-shifting, contexts like (14-15) are interesting, because while the verbs' selectional restrictions may lead us to assume a conceptual shift to $e_{\text {human }}$, the use of $s e$ in these standardFinnish contexts argues against this. In the present paper, the main cue that is relevant for us is the default pronoun used in standard Finnish text for reference to the animal in question. If it is $s e$, I assume that the animal has not been typeshifted into $e_{\text {human }}$. This is because in standard Finnish, humans are not referred to with se. 
'Bernie ${ }_{\mathbf{i}}$ went into the shower room and turned the water on full. Mentally, $\mathbf{i t}_{\mathbf{i}}$ was already planning its speech in front of the whole dog community. $\mathbf{I t}_{\mathbf{i}}$ also wondered about how everything would turn out...'

(15) 'Se' used for Pate the reindeer with a mental state description

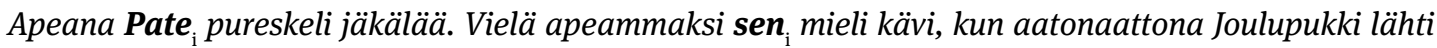
kierrokselleen. (Kanto, p.14)

'Pate ${ }_{i}$ glumly chewed on some lichen. Its ${ }_{\mathbf{i}}$ mind became even more glum when Santa Claus departed for his rounds the day before Christmas.'

So far, we have been focusing on animal examples from books written originally in (standard) Finnish. Interestingly, there are also cases of books originally written in English that used she/he for animals in the English original that are translated into Finnish with se as the default animal form (e.g. Olga da Polga by Michael Bond, about a guinea pig, translated into Finnish by Eila Kivikkaho). This is further evidence for the observation that anthropomorphized, protagonist animals can be felicitously referred to with se in Finnish. This idea that the use of hän alternation for animals cannot be explained away simply as anthropomorphism has also been mentioned in earlier work on Finnish (e.g. Laitinen 2002, 2005, 2009, 2012, Siitonen 2008), although use of se for anthropomorphized vs. non-anthropomorphized animals has not been systematically investigated.

There is also a second reason why potential complications about authors treating animals as [+HUMAN] (typeshifting from $e_{\text {animate }}$ to $e_{\text {human }}$ ) need not concern us here. This is because of the nature of the corpus that I used: to ensure that the cases of hän that we consider in this paper are not cases of animals being treated as featurally [+HUMAN] - i.e., being typeshifted to the ontological subtype $e_{\text {human }}-$ in the texts, I excluded all books from the corpus analysis that used hän as the regular/default form for animals. The sources of corpus examples used in the current work are listed in (21). All of the examples that I analyzed are from books where se is clearly the unmarked form for animals throughout the text. Texts where hän is the default form for animal reference (e.g. the Finnish translation of Michael Bond's Paddington Bear) are excluded. ${ }^{14}$

(16) Novels used for corpus study

- Kanto, Anneli. 2015. Radio Korvatunturi. Hämeenlinna, Karisto Oy. [a reindeer is the main character]

- Hytönen, Ville. 2014. Ötökkämaan tarinat. Helsinki, Tammi. [various insects]

- Huovi, Hannele. 2000. Suurkontio Tahmapää. Helsinki, Tammi. [a bear, a moose and a hedgehog]

- Kukkanen, Liisa. 2014. Koiraenkelit 1 - Bernie ja Tiina. SudenHenki. [a dog]

- Huovi, Hannele. 2016. Urpo, Turpo ja Ihanaa. Tammi. [three toys: two bears and a horse]

- Bond, Michael. 1974. ${ }^{15}$ Olga da Polga. Helsinki, Weilin \& Göös. (translated into Finnish by Eila Kivikkaho, original title Olga da Polga) [a guinea pig]

- Bond, Michael. 1974. Olga ja Vasili Vaski. Helsinki, Weilin \& Göös. (translated into Finnish by Eila Kivikkaho, original title Olga da Polga meets her match) [a guinea pig]

14 Relatedly, as my focus is on the hän/se alternation, my corpus differs from the 18th century Finnish classic Seitsemän veljestä ('Seven brothers', by Aleksis Kivi), discussed by Laitinen (2009, see also Mikkola \& Laitinen 2013), where animals are consistently referred to with hän. As Laitinen (2009) notes, at that point in time writers varied in how they used pronouns to refer to animals in written Finnish.

15 The English originals (originally published in 1971 and 1973 by Penguin Books (Olga da Polga) and Longman Young Books (Olga da Olga meets her match) consistently use she and he for animals. For example, the main character, a guinea pig called Olga da Polga, is consistently referred to with she in the English-language original, not with it. The Finnish translator, however, uses se ('it') as the default form for Olga and the other animals. 


\subsection{Predictions for reference to animals}

As we saw above, the default form for referring to animate [-HUMAN] referents (animals) in both standard and colloquial Finnish is se. Thus, one of the basic empirical questions I investigate is whether hän is also used for [-HUMAN] animal referents in linguistic contexts where the animals are still grammatically [-HUMAN] - i.e., have not been transformed such that hän would become the default form. If we do find hän being used for animals in texts where se is still the 'animal default,' we can then ask what linguistic contexts trigger the use of hän.

Let us consider what Hypotheses 1 and 2, sketched out in Section 4, would predict. According to Hypothesis 1, the association between hän and SELF exists in both standard and colloquial Finnish and takes priority over register defaults, and thus we expect to see use of hän for [-HUMAN] animals only in the specific contexts where that animal is SELF. Although the prediction is the same for colloquial and standard Finnish, standard Finnish is the more informative case. This is because, as shown in (12), colloquial Finnish does not distinguish [+HUMAN] and [-HUMAN] referents. Thus, this system allows hän to refer to animals that are attitude holders/SELF referents in colloquial Finnish without any kind of [-HUMAN]/[+HUMAN] clash: The register default does not pose any kind of featural conflict to this.

Unlike the colloquial Finnish system, by default the standard Finnish system uses hän for [+HUMAN] referents. Let us now consider what happens when an animal is the SELF/the attitude holder in standard Finnish. If the register default is to realize [-HUMAN] referents with se, then the more specific association between hän and SELF requires a violation of the register default. Thus, standard Finnish offers an ideal context in which to test the strength of the association between SELF and hän that has been posited based on prior work with human referents. The key question is whether speakers use hän for animal [-HUMAN] referents in standard Finnish that are [SELF], thereby violating (i) the register default which states that [-HUMAN] referents are realized with se and also (ii) the register default that states that [+HUMAN] referents are realized with $h \ddot{a} n$ ? If yes, this would provide strong evidence in favor of the claim that hän is indeed a logophoric pronoun in standard Finnish (in addition to the evidence we already have from colloquial Finnish, see e.g. Laitinen 2002, 2009, 2012, Mikkola \& Laitinen 2013), and that its logophoricity is separable from the [+/- HUMAN] feature.

Recall that based on human referent data, we also considered Hypothesis 2 (12'), which posits different logophoric systems for colloquial and standard Finnish. According to this approach, in (i) standard Finnish, the register defaults state that $h a ̈ n$ is only used for [+HUMAN] referents and se only for [-HUMAN] referents, and that se has an additional perspectival anti-logophoric [-SELF] function. In contrast, in (ii) colloquial Finnish, the default form se refers to [+/-HUMAN] referents, and hän to logophoric [SELF] referents. In sum, under this view, colloquial Finnish has a logophoric pronoun (hän) and standard Finnish has an antilogophoric pronoun (se).

Hypothesis 2 predicts a clear asymmetry in terms of which forms are used for animals in standard and colloquial Finnish: like Hypothesis 1, it predicts that in colloquial Finnish, hän can be used for [-HUMAN] animals if they are [SELF]. Crucially, it also predicts that in standard Finnish, hän cannot be used for [-HUMAN] animals, even if they are [SELF], because standard Finnish only has an antilogophoric pronoun (se). This prediction of Hypothesis 2 seems to be in line with a comment made by Laitinen (2009:125) that the logophoric use of hän for either humans or animals did not become an established part of standard Finnish, though she notes that some $19^{\text {th }}$ century authors used it in stream-of-consciousness contexts and when reproducing colloquial speech (Laitinen 2009:125).

In sum, the forms used to refer to animals in standard Finnish are the crucial test case to distinguish between two competing analyses of logophoric pronouns in Finnish (Hypothesis 1 vs. Hypothesis 2), and more specifically to test the strength of the association between hän and SELF. To assess what forms are used for referring to animals that are logophoric SELF referents, in the following sections, we first consider animal-referring pronouns embedded under attitude verbs (Section 6), then turn to Free Indirect Discourse contexts (Section 7) and finally consider the use of pronouns in de re contexts (Section 8). 


\section{Animals: perspective-sensitivity under attitude verbs}

In this section, we turn to naturally-occurring examples from colloquial dialects and standard Finnish to test whether attitude verbs with animal subjects can license the use of $h a ̈ n$ in the embedded clause. We only consider texts where the default form for animals is clearly se.

In colloquial Finnish, in contexts where it is clear that se is the default form that is normally used to refer to an animal, hän can nevertheless be used to refer to that same animal under a variety of attitude predicates. The colloquial examples in (17-18), referring to animals, are from Laitinen (2002:333). Ex. (17) is about a magpie ${ }^{16}$, ex. (18) about a dog. As above, I translate Finnish hän as 'she/he' in English and Finnish $s e$ as 'it' in English, in order to make the alternation between the different forms easier to see.

(17) En tiet tiennöö-kö tuo sitte ite-kkääm mihinkä häv $v_{i}$ vei se Neg.SG1 know knows.POT-CL it.NOM $\mathbf{m}_{\mathrm{i}}$ then self-CL where she/he.Nom took it.ACC 'I don't know if that ${ }_{i}$ itself (the magpie) even knows where she/he took it (the spoon)'

(18) Mut koera $_{\mathrm{i}}$ jos otta-a ni se $\boldsymbol{i}_{\mathrm{i}}$ tietä-ä että mihinkä hän $\boldsymbol{\mathrm { i }}_{\mathrm{i}}$ viep

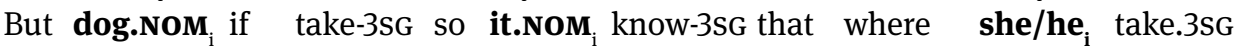
'But if the $\mathbf{d o g}_{\mathbf{i}}$ takes something, it ${ }_{\mathbf{i}}$ knows where $\mathbf{s h e} / \mathbf{h e}_{\mathbf{i}}$ takes (it)'

Crucially, my corpus data shows that the same kind of se...hän pattern is present with animals in standard Finnish, with a variety of attitude predicates, as illustrated in ex. (19-22). Again, I translate Finnish se into English as it, and Finnish hän into English as she/he. Examples (19-21) are from books written in standard Finnish. Example (22) is from the internet, where the register may be less 'standard' than in novels. Nevertheless, the verb morphology uses standard Finnish forms and the sentence structure (e.g. participial constructions) is in line with standard, not colloquial, Finnish.

These are all contexts where (as the examples show), se is the default form used for the animal referent. Thus, the use of $h \ddot{n} n$ cannot be attributed to a register default. ${ }^{17}$

(19) thought predicate

[Context: Tiina tells Juppe to not lick her; she does not realize Juppe is a 'reincarnation' of her dog Bernie] Eihän kielto oikeastaan edes koskenut sitä ${ }_{i}$, koska Tïna kielsi jotakin Juppea nuolemasta itseään. Mutta samalla sekunnilla Bernie i $_{\mathrm{i}}$ ajusi, että kyllä kielto koski juuri hänt $\ddot{a}_{i} \ldots$.. (Kukkanen, p.39)

'Actually the prohibition did not even refer to it, because Tiina was telling some Juppe to stop licking her. But in that same moment Bernie ${ }_{i}$ understood that the prohibition did apply precisely to him.'

(20) thought predicate

[Context: A woman tries to convince a squirrel (called Tamppi) to come eat some of the nuts she is offering.]

Orava $_{i}$ mietti, miksi täti tahtoi antaa hänelle ${ }_{i}$ pähkinöitä. (Huovi, p.30)

'The squirrel ${ }_{i}$ pondered, why the lady wanted to give him $_{\mathrm{i}} /$ her $_{\mathrm{i}}$ nuts.

(21) Example showing that the default form for the squirrel in (20) is 'se':

[Context: Tamppi, the squirrel, startles the woman by jumping onto her arm, so that the woman accidentally drops the bag of nuts.]

Tamppi juoksi tätiä pitkin maahan. Se nappasi pähkinän, loikkasi pensaaseen ja katosi. (Huovi, p.32)

'Tamppi ran down along the woman. It grabbed a nut, jumped into a bush and disappeared.'

16 In this example, the pronoun in the matrix clause is the distal demonstrative tou rather than se. What is most relevant for our purposes is the use of (a dialectal form of) hän in the embedded clause.

17 As discussed in Section 1, morphological properties independent of hän and se can also be used to determine whether a certain text is in standard or colloquial Finnish. 
(22) knowledge predicate

[Context: Pet owners writing about dog behavior]

Mutta kuitenkin miten koiraan sen $_{i}$ muristessa sïhen on suhtauduttu, on voinut myös edellisessä

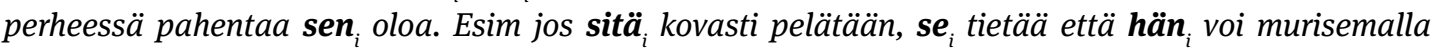
saada asioita läpi. Samalla ihmisestä riippuen, ja ehkä pentuaikana kun se $\boldsymbol{e}_{i}$ on pieni ja alkaa osoittaa ensimmäiset murinansa, sitä ${ }_{i}$ vielä sïnä vaiheessa retuutetaan ja uhataan....

http://www.koiraneuvola.fi/keskustelu/viewtopic.php?p=60474 (4/7/2010)

'But nevertheless, the way that the $\operatorname{dog}_{\mathrm{i}}$ was treated when it ${ }_{\mathrm{i}}$ growled may have, in its prior family, made $\mathbf{i t}_{\mathrm{i}}$ feel worse. For example if $\mathbf{i t}_{\mathrm{i}}$ is badly feared, $\mathbf{i t}_{\mathrm{i}}$ knows that $\mathbf{s h e} / \mathbf{h e}_{\mathrm{i}}$ can get things by growling. Also, depending on the person (owner) and maybe when $\mathbf{i t}_{\mathrm{i}}$ was a puppy and started to growl, if it ${ }_{\mathrm{i}}$ was still dragged around and threatened...'

In sum, we find that in both colloquial and standard Finnish, in contexts where se is the standard form for animals, hän can be used when embedded under a range of attitude predicates including thought and knowledge. The fact that se is still the default form for the animal referent in these contexts signals that the animals have not been typeshifted and are still featurally [-HUMAN]. Thus, we have evidence that $h a ̈ n$ can be logophoric when embedded under attitude verbs in both colloquial and standard Finnish. The finding that hän can be used for [-HUMAN] referents in standard Finnish as well as colloquial Finnish goes against the predictions of Hypothesis 2 and is in line with Hypothesis 1. More specifically, the fact that hän can be used to refer to [-HUMAN] referents as long as they are [SELF] referents suggests that, at least on its logophoric use, hän does not require its referent to have a [+HUMAN] feature. In other words, the specific mapping between $[\mathrm{SELF}]$ and $h \ddot{n}$ can override the register default.

\section{Animals: perspective-sensitivity in main clauses in free indirect discourse}

The presence of the hän/se alternation with reference to animals is not limited to contexts of embedding under attitude verbs: examples in this section show that it also exists in matrix clauses. Examples (23) and (24), from a children's book by Ville Hytönen, show that the same animal character (a spider called Hämämäkämäkki) is normally referred to with the default form se, even in mental state contexts as in ex. (23) - i.e., anthropomorphic behavior is not enough to trigger use of $h \ddot{n}$. At the same time, we see that hän is used to refer to the spider even when it is not syntactically embedded under an attitude verb (ex.24), if the context involves FID from the animal's perspective. Similarly, in a book about a guinea pig called Olga by Michael Bond, the default form used by the Finnish translator for the guinea pig is se (ex.25) - but hän is also used, even in unembedded main-clause contexts (ex.26). (The English translations are by the present author; they are not the sentences from the English original.)

These unembedded contexts where hän is used can be characterized as presenting the thoughts of the animal character: the author gives the reader a glimpse inside the mind of the animal, the SELF. In other words, these contexts involve Free Indirect Discourse (FID).$^{18}$ For example, in ex. (24), use of the wh-exclamative provides a strong indication that the sentence conveys the spider's thoughts (see also Banfield (1973:10-11) on exclamatives as cues for FID). Similarly, in ex. (26), use of the sentence-initial combination of the copular verb and the discourse clitic - $p a$ ('was+clitic') provides affective/expressive information which signals FID (see also Banfield 1973, McHale 1978, Fludernik 1993 on properties of FID). Furthermore, it is worth noting that in contexts where animals are described, from an external observer's perspective, as engaging in mental acts (e.g. feeling sad in ex.29), the non-human pronoun se can still be felicitously used. It is specifically in contexts that are construed as being in the scope of FID (i.e., where the text conveys the animal's thoughts, without embedding under an attitude verb) that we find use of $h a ̈ n$ with SELF antecedents that are animals.

18 See also discussion in Laitinen (2009:125) on pronoun use in Finnish novels of the late 1800s and early 1900s, though she concludes that a logophoric use of hän is not established in standard Finnish. 
(23) Se is the default from used to refer to the animal in question

[Context: A spider called Hämämäkämäkki feels bad about eating other insects]

Hämämäkämäkille $e_{i}$ oli kuitenkin opetettu, että sen täytyi syödä muita ötököitä.... (...) Hämämäkämäkillä ${ }_{i}$ oli huono mieli koska se oli $_{\mathrm{i}}$ taas syönyt jonkun metsän ötököistä. (Hytönen, p.40) 'Hämämäkämäkki ${ }_{i}$ had been taught that it $_{i}$ needed to eat other bugs [...] Hämämäkämäkki ${ }_{i}$ was sad because $i_{i}$ had again eaten one of the forest's bugs'

(24) Hän used to refer to the same animal in an FID context

[Context: An insect gets caught in the spider Hämämäkämäkki's web, and begs not to be eaten, explaining that it is endangered and expected home for dinner]

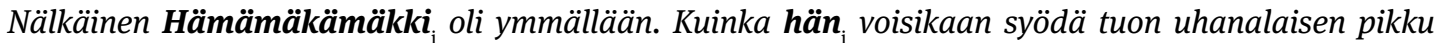
perhosen, varsinkin kuin sen pitäisi itse lentää kotiin illalliselle. (Hytönen, p.40)

'The hungry Hämämäkämäkki ${ }_{\mathrm{i}}$ was confused. How could she/he $\mathbf{i}_{\mathrm{i}}$ eat that endangered little butterfly, especially since it itself needed to fly home for dinner.'

(25) $S e$ is the default form used to refer to the animal in question

[Context: Olga, a guinea pig, watches a toad jump across the yard and decides to try to imitate it]

Olga $_{\mathrm{i}}$ vilkaisi, ettei ketään ollut lähellä, sitten se $\boldsymbol{e}_{\mathrm{i}}$ kokeili osaisiko loikkia samalla tavoin, mutta hyppyyn ei ensinnäkään tullut tarpeeksi pituutta ja sitten se $\boldsymbol{e}_{\mathrm{i}}$ vielä törmäsi päistikkaa mökkinsä seinään. (Bond/ Kivikkaho, Olga da Polga ja Vasiki Vaski, p.91)

'Olga ${ }_{i}$ glanced to make sure no one was nearby, then it $_{\mathrm{i}}$ tried jumping the same way, but the jump was not long enough and then $\mathbf{i t}_{\mathbf{i}}$ also crashed directly into the wall of its little house.'

(26) Hän used to refer to the same animal in an FID context

[Context: Olga hears the mother of the family express her disapproval at the presence of a toad in the backyard, which the mother says had been attracted by an outdoor pool set up by the father]

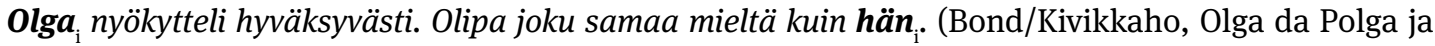
Vasiki Vaski, p.90)

'Olga ${ }_{i}$ nodded approvingly. For once someone had the same opinion as she did.' $^{\prime}$

Ex. (27) illustrates that not only can hän be used to refer to an animal that is SELF, but that in such contexts we also see se being used to refer to the non-SELF. This is the same pattern that obtains when both the SELF and the non-SELF are human (see Kaiser 2018 for examples).

(27) [Context: The guinea pig Olga is still in the pet shop at the start of the story, and thinks about another guinea pig who has been returned to the pet shop and who has told scary stories about people and how strict they are]

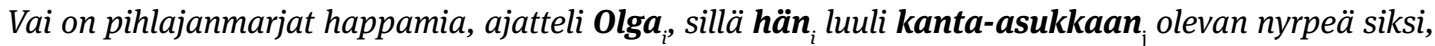
että $\boldsymbol{s}_{\mathrm{j}}$ oli joutunut tulemaan takaisin kauppaan. (Bond/Kivikkaho, Olga da Polga, p.11)

'Sour grapes, thought Olga $_{i}$, because she ${ }_{i}$ thought that the reason that Long-Term Inhabitant ${ }_{j}$ was grumpy was because it ${ }_{j}$ had been forced to come back to the (pet) shop.'

Additional examples showing use of hän in FID contexts come from a young adult novel called "Bernie ja Tiina" (Kukkanen, 2014). The story is about a dog, Bernie, that is sent down from "dog heaven" to help a young girl convince her parents that she should have a dog. The novel is written in standard Finnish, so - just like in the case of the other novels mentioned above - the default pronoun for humans is hän and the default for animals, including Bernie, is se. Ex. (28) (originally presented as ex.14) shows that even in contexts where Bernie is personified and engaging in mental activities (e.g. thinking and planning an upcoming speech), the nonhuman pronoun se is used. Thus, as we already discussed in Section 5.1, anthropomorphism, in the absence of FID or an embedding attitude verb, does not trigger use of hän. 
(28) Bernie $_{\mathrm{i}}$ meni suihkuhuoneeseen ja väänsi veden täysillä valumaan. Mielessään $\boldsymbol{s}_{\mathrm{i}}$ jo suunnitteli puhettaan koko koirayleisön edessä. Se $\boldsymbol{e}_{\mathrm{i}}$ mietti myös millainen tarinan loppu voisi olla... (Kukkanen, p.50)

'Bernie ${ }_{\mathbf{i}}$ went into the shower room and turned the water on full. Mentally, $\mathbf{i t}_{\mathbf{i}}{ }_{\mathbf{w}}$ was already planning its speech in front of the whole dog community. $\mathbf{I t}_{\mathbf{i}}$ also wondered about how everything would turn out...'

Nevertheless, there are numerous examples of hän being used for Bernie inside FID contexts, as in (29-30) below. However, the default se can also be used in FID for SELF referents, as in ex. (31):

(29) [Context: Tiina's mother had commented on the odd size relation between Bernie, who is very big, and the size of his dog food bag, which is rather small]

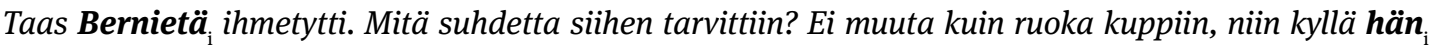
sille suhteita osoittaisi. Suorinta tietä vatsaan ja sillä hyvä (Kukkanen, p.23)

'Bernie $_{\mathbf{i}}$ was confused again. What kind of relation did that need? Just put the food in the cup, and he $\mathbf{~}_{\mathbf{i}}$ would show it the right kind of relation. Straight to the stomach and that's it.'

(30) [Context: Bernie has been locked into the kitchen to sleep at night]

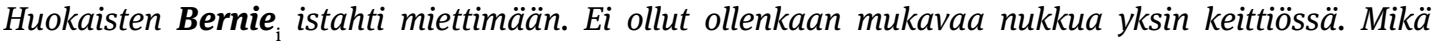

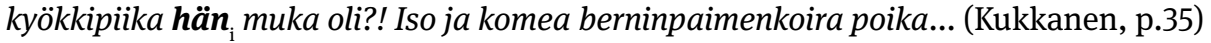

'With a sigh, Bernie ${ }_{i}$ sat down to think. It was no fun to sleep alone in the kitchen. What kind of scullery maid was he $\mathbf{e}_{\mathbf{i}}$ ? A big and handsome Bernese mountain dog...'

(31) [Context: Tiina's father and brother find an announcement for a dog that went missing in Lahti, and think that maybe Bernie is that missing dog]

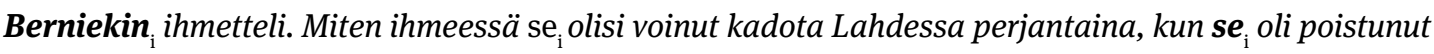
vasta sunnuntaina Koirien Taivaasta? (Kukkanen, p.40)

'Bernie $_{\mathbf{i}}$ was surprised too. How on earth could $\mathbf{i t}_{\mathbf{i}}$ have disappeared in Lahti on Friday, when $\mathbf{i t}_{\mathbf{i}}$ had only left the Dogs' Heaven on Sunday?

In sum, similar to what we see in reported speech/thought contexts, the corpus data show that hän can be used in standard Finnish in Free Indirect Discourse (FID) contexts to refer to the logophoric SELF, even if it is an animal. ${ }^{19}$ This provides clear evidence than hän can refer to SELF even in standard Finnish something that was hard to see with reference to humans because hän is the register default for humans. This again supports Hypothesis 1 and goes against Hypothesis 2. This finding also corroborates my earlier observation (Section 6) that use of hän for a [-HUMAN] SELF referent is possible despite the register-default link between [+HUMAN] and $h \ddot{n}$.

Nevertheless, the fact that se can also be used in FID contexts for SELF referents (ex.31) shows that it is still the default form for non-human animals. So, we have seen that with non-human referents, se - which is the default - can be used in non-logophoric/non-SELF as well as in logophoric/SELF-referring contexts, but the non-default human pronoun hän is only used when referring to SELF, in FID or reported speech contexts.

19 As discussed by Mikkola \& Laitinen (2013) historical varieties of Finnish (before the modern standard Finnish conventions stabilized) could use hän to refer to animals when they were conceptualized as beings whose motives/thoughts/feelings could be understood and who engaged in meaningful interactions with humans (see also Laitinen 2009, 2012). Mikkola and Laitinen cite ex. (i) from an advice book for children (late 1800s), and note that se is used when the animal is simply the target of observation but $h a ̈ n$ is used when the animal is viewed as a 'persona' that understands interactions and has feelings. The present paper focuses on present-day Finnish but it is clear that the use of $h a ̈ n$ for animals that are presented as the SELF is not a new phenomenon. (i) Jos kohtaat wihollises eläimen eksyksissä: niin johdata hänet isännällensä. Älä katsele sitä langenneena tiellä; wan auta kuorman edessä wäsynyttä (cited by Mikkola \& Laitinen 2013:485) 'If you meet your enemy's lost animal $\mathbf{l}_{\mathrm{i}}$, lead $\boldsymbol{h i m}_{\mathrm{i}}$ back to his owner. Do not look at it fallen on the road but help the one tired by the heavy load' (my informal translation) 


\section{De se and de re reference to animal antecedents}

It is often suggested in prior work that logophoric pronouns are obligatorily interpreted de se (i.e., the antecedent is aware that she/he is the referent of the pronoun) in Ewe and in other languages (e.g., Schlenker 1999, Stephenson 2007, see also von Stechow 2003), and cannot receive a de re interpretation (where the antecedent is not aware that she/he is the referent of the pronoun). Initial empirical evidence that supports this, at least for some languages, comes from Bafut (Kusumoto 1998, see ex.32), Yoruba (Anand 2006), and Tangale (Haida 2009). Schlenker (2003) provides the example in (32) from Bafut and notes that use of the logophoric pronoun $y u$ is ungrammatical in a de re context, when John does not realize that the man whose pants are on fire is him. However, the view or assumption that logophoric pronouns are universally obligatorily de se is challenged by Pearson (2015), based on data from Ewe. Based on fieldwork, Pearson shows that Ewe logophors are not obligatorily de se and also allow de re readings.

(32) Situation (Kaplan 1977): John is looking at a mirror from a distance and sees a man in the mirror. He notices that the man's pants are on fire. In fact, the man he sees in the mirror is John himself, but he doesn't realize it.

a. John believes that his pants are on fire

b. John wà?àto mo $\left\{^{*} y u /\right.$ à $\} \quad k a ́$ khi (Bafut; P.Tamanji, p.c to Kiyomi Kusumoto) John thinks that $\{$ LOG / he $\}$ FUT burn

'John thinks that he is going to get burnt'

Investigating whether Finnish hän can be used in both de re and de se contexts or only in de se contexts provides another way to probe its logophoric properties. As in the preceding sections, we focus here on reference to animals, since with humans use of $h a ̈ n$ could be triggered by its being the default form. Recall, though, that as we saw in Section 3.3, in standard Finnish Free Indirect Discourse with humans, se is used for the non-SELF and hän for the SELF. Based on those patterns, we might expect that (i) hän is used only for de se readings and (ii) $s e$ is used for de re readings.

For Finnish, my corpus data shows that in mistaken identity contexts with animals, (i) logophoric hän is used for de se reference and (ii) se is used for de re or de se reference. The examples from my corpus do not involve embedding under attitude verbs but rather are contexts with Free Indirect Discourse. Consider examples (33-34) below. Ex. (33) is from a book about a reindeer, Pate, who is normally referred to with se. This extract describes a context where Pate sees his reflection in a window, but does not realize that it is him (or his reflection), and thinks it is a monster. When referring to the 'monster' in Pate's belief world, the author uses se in the third sentences (de re), and when referring to Pate, the author either uses se (sentence 2) or hän (sentence 5) in an FID context where Pate is the perspectival center. Immediately after this extract, the author goes back to referring to Pate with se.

(33) Pate veti henke $\ddot{a}_{\text {sentencel }}$. Ikkunan toisella puolella se näki häijysti irvistelevän, sarvipäisen kammotuksen,

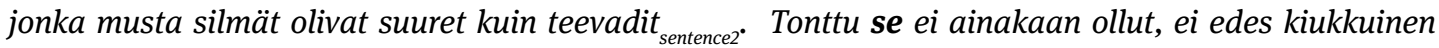

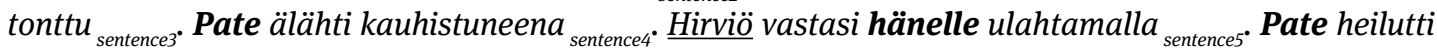
korviaan $_{\text {sentencee }}$. Hirviö heilutti myös sentencet $_{\text {(Kanto, p.81-82) }}$

'Pate took a breath sentencel . On the other side of the window it saw a nastily grimacing, horned dreadful creature, whose black eyes were as big as tea-saucers ${ }_{\text {sentencer: }}$ It definitely was not an elf, not even an angry elf sentence3. Pate let out a terrified yelp sentence4 . The monster answered him with a yelp sentences. Pate

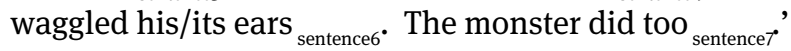

Similarly, in ex. (34), we have another mistaken identity scenario from a different book. Here, the moose Iiro sees his reflection in the window of the shopping center but does not realize it's him, and instead thinks it is another moose. Similar to ex. (33), in this context the default form for liro is se, as the first few sentences show. As in ex. (33), there is no embedded verb, and both hän and se occur inside the FID domain. When 
Iiro is the SELF, hän is used (sentence 5), and at same time, de re reference (sentence 8) is done with the default form $s e .20$

(34) Iirolähtiostoskeskukseen sentencer $_{\text {Se }}$ kulkikävelytietäaivansääntöjen mukaan.... sentence2 (....) Ostoskeskuksessa

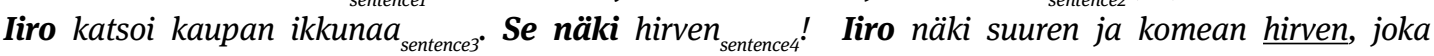

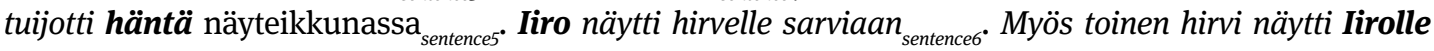
sarviaan $_{\text {sentencę }}$ Se oli ajettava pois sentences: $^{\text {. Tämä oli Iiron ostoskeskus }}$ sentences (Huovi, p.63-64)

'Iiro headed towards the shopping center ${ }_{\text {sentencel }}$. It walked along the pedestrian route exactly as the rules stated..... sentence2 $(. .$.$) In the shopping center, liro looked at a store window$ sentence3 . It saw a moose sentence4! Iiro saw a big and handsome moose who stared at him from the window sentences $^{\circ}$. Iiro showed the moose its/his horns sentence6 $_{\text {. The other moose showed liro its/his horns too }}$ sentencer $_{\text {It }}$ It must be chased away $_{\text {sentences }}$. This was Iiro's shopping center ${ }_{\text {sentences }}$ '’

It is worth emphasizing that that these 'mistaken identity' contexts differ in a meaningful way from the standard FID examples we considered in Section 7. In ex. (34), in the 'actual world' of the narrative, both hän and se actually refer to the moose, Iiro. (The same logic applies to ex.(33)). This differs crucially from regular FID examples, where hän and $s e$ - when inside the FID domain - refer to fully distinct entities. Thus, the mistaken identity examples highlight that the 'non-SELF' is based on the epistemic state of the $S E L F$. What matters for use of $s e$ is not that it has to refer to an entity that is not coreferential with the SELF, but rather that the SELF does not recognize the other referent as being coreferential with the SELF. The idea that what matters is the epistemic state of the SELF is in line with Kaiser (2018)'s claim - based on other evidence - that the logophoric SELF use of hän is the fundamental property that also drives the association of $s e$ with the non-logophoric SELF.

In sum, with animals, hän is used for de se reference, and se (the default) for de re or de se. I found no corpus examples of hän being used in a de re context. This observation receives further support from native speaker judgements of pronouns embedded under attitude verbs, which suggest that logophoric hän cannot be felicitously used in a de re context with animal antecedents. To see this, consider a constructed example where liro tells other animals about his experience with the 'interloper' moose (ex.35a) and then one of the animals reports to someone else what Iiro had said (ex.35b,c). Use of the default form se is fine (ex.35c), but use of $h \ddot{n}$ in the embedded clause in (35b) is infelicitous, indicating that it cannot be used felicitously in de re contexts.

(35) a) Iiro kertoi hirvestä toisille eläimille. Se oli ihan tohkeissaan siitä, että vieras hirvi oli ollut Iiron ostoskeskuksessa. "Se hirvi oli väärässä paikassa!", Iiro selitti.

'Iiro told the other animals about the moose. It was all wound up about (the fact that) the strange moose had been in Iiro's shopping center. "The moose was in the wrong place!” Iiro explained.'

b) Later on, one of the animals explains to someone else what Iiro had said:

Se sanoi, että \# hän oli väärässä paikassa.

'It said that \#she/he was in the wrong place.'

c) Later on, one of the animals explains to someone else what Iiro $_{\mathrm{i}}$ had said:

Se sanoi, että se oli väärässä paikassa.

'It said that it was in the wrong place.'

\section{Conclusions}

This paper set out to gain insights into our linguistic conceptualization of non-human animals, what this can tell us about how perspective-taking is signaled linguistically, and how this relates to features such as [+/-HUMAN]. Empirically, the question I investigated is whether, in contexts where animals are clearly

20 When Finnish uses only a possessive suffix without an overt possessive pronoun, human and non-human animal reference is not morphologically distinguished. These 'uninformative' occurrences are denoted with 'it/he' or 'it/she' in the translations. 
grammatically [-HUMAN], the linguistic system of Finnish still allows us to treat animals grammatically as entities with the ability to experience mental states and attitudes. I probed this by exploring whether animals can be referred to with logophoric pronouns in different linguistic contexts and registers. Finnish is especially well-suited for this investigation because it has a pronoun with logophoric properties which is the same form as the human-referring pronoun used in standard Finnish, hän (she/he). This allows us to test whether a pronoun, hän, that may at first blush seem featurally specified to seek [+HUMAN] referents, can nevertheless be used for [-HUMAN] referents, animals, when these referents are logophoric centers, in both standard and colloquial Finnish. In related work, Peltola (this issue) investigates Finnish constructions often viewed as grammatically requiring [+HUMAN] referents, namely the zero person construction and the impersonal passive, to see whether they can be used for non-human animals, and if so, when.

Given that thinking, speaking and mentalizing are fundamentally human traits, it might not be surprising if logophoric pronouns were only restricted to humans. To the best of my knowledge, prior crosslinguistic and typological work on logophoric pronouns has not systematically investigated whether these forms can be used for sentient thinkers or 'mental state experiencers' that are still grammatically clearly [-HUMAN], except for Laitinen's (2002, 2009, 2012) work on historical Finnish and dialects of colloquial Finnish (see also Mikkola \& Laitinen 2013). This question also relates to broader issues concerning semantic and pragmatic features, such as the extent to which discourse-semantic features such as logophoricity - which can change over the course of a narrative - can 'overpower' arguably more immutable semantic features such as the [+/-HUMAN] distinction.

Furthermore, investigating logophoric reference to animals allows us to shed light on questions left open by prior work on human reference with logophoric pronouns (see e.g. Kaiser 2018). When investigating the Finnish logophoric system by looking at reference to humans, complications arise from differences between standard and colloquial Finnish; specifically, it is hard to detect whether hän 'she/he' is logophoric not only in colloquial but also in standard Finnish. Indeed, Laitinen (2009) suggests that $h a ̈ n$ is widely used logophorically in colloquial but not in standard Finnish.

In the present paper, I focus on reference to animals because, unlike reference to humans, which shows register variation in Finnish, the default form for animals does not change across registers and offers a clearer view of the logophoric system. Based largely on corpus data, supplemented by native speaker intuitions, I investigated use of se 'it' and hän 'she/he' in reference to animals both in contexts where the forms are embedded under attitude verbs as well as main clause contexts. My discussion is also informed by additional corpus data and discussion from Laitinen (2002) (see also Laitinen 2009, 2012; Mikkola \& Laitinen 2013 for historical data on animal reference). I use this data to assess the validity of two competing hypotheses: (i) the view that hän is logophoric in both registers in Finnish vs. (ii) the view that the two registers have different logophoric pronoun systems. I argue that the data points towards the former, i.e., a unified system where hän is logophoric in both standard and colloquial Finnish. Furthermore, I conclude that hän can be used to refer to [-HUMAN] referents - in both standard and colloquial Finnish, in both embedded and main clause contexts - as long as they are logophoric [SELF] referents. This suggests that, at least on its logophoric use, hän does not require its referent to have a [+HUMAN] feature. I conclude that the specific mapping between [SELF] and hän can override the register default that would otherwise associate hän with [+HUMAN] referents in standard Finnish.

Further evidence in line with the idea that perspectival factors can 'overcome' associations with [+HUMAN] referents comes from Peltola (this issue). Peltola investigates two Finnish constructions traditionally viewed as requiring [+HUMAN] referents, namely the zero person construction and the impersonal passive. Using corpus data, she shows that these constructions (as well as modals) can be used to refer to animals in contexts where the event is construed from the point-of-view of the non-human animal and where the speaker/writer "seek[s] to make sense of the animal referent's behavior" (Peltola, this issue).

The findings discussed in this paper have consequences for our view of semantic and pragmatic features, in particular the extent to which discourse-semantic features such as logophoricity can overpower more immutable semantic features such as the [+/-HUMAN] distinction. If one wants to regard hän as being specified as [+HUMAN], then the results presented in this paper for animal reference suggest that being the 
logophoric SELF is able to 'override' the [+HUMAN] specification of the pronoun. Whether such a view of feature override is on the right track - or, alternatively, perhaps the feature specification of hän is different from what is often thought - is an important question for future work.

Acknowledgments: Many thanks to two anonymous reviewers for helpful and thoughtful comments. In addition, I would also like to thank the editors of this special issue, Diane Nelson and Virve-Anneli Vihman, for their detailed feedback on my paper.

\title{
Abbreviations used
}

\author{
ACC accusative case \\ ADESS adessive case \\ ALL allative case \\ CL clitic \\ COMPL complementizer \\ INESS inessive case \\ LOG logophoric pronoun \\ NEG negation \\ NOM nominative case \\ PAR partitive case \\ PL plural \\ PST past \\ PTCP participle \\ PX possessive suffix \\ SG singular
}

\section{Sources}

Bond, Michael. 1974. Olga da Polga. Helsinki, Weilin \& Göös. (translated into Finnish by Eila Kivikkaho)

Bond, Michael. 1974. Olga ja Vasili Vaski. Helsinki, Finland: Weilin \& Göös. (translated into Finnish by Eila Kivikkaho)

Huovi, Hannele. 2000. Suurkontio Tahmapää. Helsinki, Finland: Tammi.

Huovi, Hannele. 2016. Urpo, Turpo ja Ihanaa. Tammi.

Hytönen, Ville. 2014. Ötökkämaan tarinat. Helsinki, Finland: Tammi.

Joensuu, Matti Yrjänä. 1983. Harjunpää ja poliisin poika. Helsinki, Finland: Otava.

Kanto, Anneli. 2015. Radio Korvatunturi. Hämeenlinna, Finland: Karisto Oy.

Kukkanen, Liisa. 2014. Koiraenkelit 1 - Bernie ja Tiina. SudenHenki.

Polva, Anni. 1989. Taitaa olla rakkautta, Tiina. Hämeenlinna, Finland: Karisto.

\section{References}

Anand, Pranav. 2006. De de se. PhD dissertation, MIT.

Arluke, Arnold, Clinton Sanders. 1993. Regarding animals. Temple University Press, Philadelphia.

Banfield, Ann. 1973. Narrative style and the grammar of direct and indirect speech. Foundations of Language 10(1), 1-39.

Büring, Daniel. 2005. Binding Theory. Cambridge Textbooks in Linguistics. Cambridge University Press.

Charnavel Isabelle, Dominique Sportiche. 2016. Anaphor Binding - What French Inanimate Anaphors Show. Linguistic Inquiry, 47 (1) :35-87.

Charnavel, Isabelle, Chrissy Zlogar. 2015. English reflexive logophors. Proceedings of the 51st Annual Meeting of the Chicago Linguistic Society, pp. 83-97

Chemla, Emmanuel. 2008. An epistemic step for anti-presuppositions. Journal of Semantics 25(2). 141-173. doi:10.1093/jos/ ffm017.

Clements, G.N. 1975. The Logophoric Pronoun in Ewe. J. of West African Languages 2:141-177.

Cooper, Robin. 1983. Quantification and Syntactic Theory. Reidel, Dordrecht.

Culy, Christopher. 1994. Aspects of logophoric marking. Linguistics 32:1055-1094. 
Culy, Christopher. 1997. Logophoric Pronouns and Point of View. Linguistics 35:845-859.

Eddy, Timothy J., Gordon Gallup, Daniel Povinelli. (1993). Attribution of cognitive states to animals: Anthropomorphism in comparative perspective. Journal of Social Issues, 49, 87-101

Epley, Nicholas, Adam Waytz. 2010. Mind Perception. Handbook of Social Psychology. 2:II:14.

Fludernik, Monika. 1993. The Fictions of Language and the Languages of Fiction: The Linguistic Representation of Speech and Consciousness. London: Routledge.

Gardelle, Laure. 2012. Pronominal gender in references to animals. Anglophonia - French Journal of English Linguistics, 16 (32), 11-23.

Gardelle, Laure. 2013.Gender/sex discrepancies in pronominal references to animals: a statistical analysis. English Language and Linguistics 17(1):181-194.

Grice, Herbert Paul. 1975. Logic and conversation. In Peter Cole \& Jerry L. Morgan (eds.), Speech Acts, Syntax and Semantics 3 , 41-58. Academic Press.

Guthrie, Stewart. 1993. Faces in the clouds. Oxford, United Kingdom: Oxford University Press

Guzmán-González, Trinidad. 2013. Gender assignment in present-day scientific English. A case study in the field of Zoology journals. In Verdaguer, Isabel, Laso, Natalia Judith, and Salazar, Danica, eds. Biomedical English: A Corpus-based Approach. Amsterdam: John Benjamins.

Hagège, Claude. 1974. Les pronoms logophoriques [Logophoric pronouns]. BSLP, 69:287-310.

Haida, Andreas. 2009. (Proto-)logophoricity in Tangale. Handout of talk given at NELS 40, MIT.

Hakulinen, Auli. 1988. Miten nainen liikkuu Veijo Meren romaaneissa [A woman moving in the novels by Veijo Meri]. In Isosuinen nainen: tutkielmia naisesta ja kielestä, ed. Lea Laitinen, 56-70. Helsinki: Yliopistopaino.

Hakulinen, Auli, Fred Karlsson 1989. Nykysuomen lauseoppia [The syntax of present-day Finnish]. Helsinki: Suomalaisen Kirjallisuuden Seura.

Hakulinen, Auli et al. 2005. Iso suomen kielioppi [Comprehensive grammar of Finnish]. Helsinki: Suomalaisen Kirjallisuuden Seura.

Heider, Fritz, Marianne Simmel. 1944. An experimental study of apparent behavior. American Journal of Psychology, 57, 243-249.

Heim, Irene, Angelika Kratzer. 1998. Semantics in Generative Grammar. MIT Press, Cambridge, MA

Heim, Irene. 1991. Artikel und Definitheit [Articles and definiteness]. In A. von Stechow \& D. Wunderlich (eds.), Semantik: Ein internationales Handbuch der zeitgenössischen Forschung, 487-535. Berlin: de Gruyter.

Herzon, Hal. 2010. Some we love, some we hate, some we eat: Why it's so hard to think straight about animals. Harper.

Horn, Laurence R. 1984. Towards a new taxonomy of pragmatic inference: Q-based and R-based implicature. In Meaning, Form, and Use in Context: Linguistic Applications, 11-42. Washington, DC: Georgetown University Press

Huang, Yan. 2000. Anaphora: A cross-linguistic Approach. Oxford University Press.

linatti, Minna. 2015. Organisaatiokulttuurin vaikutus henkilöstövalintaan. [The impact of organizational culture on personnel selection]. Opinnäytetyö, Oulun Ammattikorkeakoulu.

Kaiser, Elsi. 2008. (Anti)logophoricity in Finnish. The Proceedings from the Main Session of the Chicago Linguistic Society's Fortieth Meeting. Volume 40-1, pp.139-153. Chicago Linguistic Society.

Kaiser, Elsi. 2018. Pronoun use in Finnish reported speech and free indirect discourse: Effects of logophoricity. In Pritty Patel-Grosz, Patrick Grosz and Sarah Zobel (eds), Pronouns in Embedded Contexts at the Syntax-Semantics Interface. Springer Studies in Linguistics and Philosophy, vol. 99, pp.75-104.

Kaplan, David. 1977/1989. Demonstratives. In Joseph Almog, John Perry, Howard Wettstein (eds.), Themes From Kaplan. Oxford University Press, pp. 481-563.

Karlsson, Fred. 1999. Finnish: An essential Grammar. Routledge.

Kuiri, Katja. 1984. Referointi Kainuun ja Pohjois-Karjalan murteissa [Reported speech in the Finnish dialects of Kainuu and North Carelia]. Helsinki: Suomalaisen Kirjallisuuden Seura.

Kusumoto, Kiyomi. 1998. Tenses as logophoric pronouns. Handout of talk given at the MIT/UConn/UMass Semantics Workshop, October 31, 1998 (UConn)

Laitinen, Lea. 2002. From logophoric pronoun to discourse particle. A case study of Finnish and Saami. In New reflections on grammaticalization, ed. I. Wischer \& G. Diewald. P. 327-344. Amsterdam/Philadelphia: John Benjamins.

Laitinen, Lea. 2005. Hän, the third speech act pronoun in Finnish. In Minimal reference in Finnic: The use and interpretation of pronouns and zero in Finnish and Estonian discourse, ed. Ritva Laury. Helsinki: Suomalaisen Kirjallisuuden Seura.

Laitinen, Lea. 2009. Vapaus ja järjestys: Eläinten kielioppi Seitsemässä veljeksessä [Freedom and order: The animal grammar in the Seven Brothers]. In Yli-Paavola, Jaakko, Pekka Laaksonen (eds.), Tulinuija: Aleksis Kiven seuran albumi, 115-131. Helsinki: Suomalaisen Kirjallisuuden Seura.

Laitinen, Lea. 2012. Luonnon ja kulttuurin kertomuksia [Narratives of nature and culture]. In Kurikka, Kaisa, Olli Löytty, Kukku Melkas, Viola Parente-Capková (eds.), Kertomuksen luonto [The nature of a narrative], 291-299. Jyväskylä: Vastapaino.

Larjavaara, Matti. 1990. Suomen deiksis [Deixis in Finnish]. Helsinki: Suomalaisen Kirjallisuuden Seura.

Lauer, Sven. 2016. On the status of “Maximize Presupposition.” Proceedings of SALT 26, pp.980-1001.

Laury, Ritva. 2005. Minimal reference: the use of pronouns in Finnish and Estonian discourse. Helsinki: Suomalaisen Kirjallisuuden Seura. (Studia Fennica; no. [12]) 
Laury, Ritva. 1997. Demonstratives in interaction: the emergence of a definite article in Finnish. Amsterdam: John Benjamins.

McHale, Brian. 1978. Free indirect discourse: A survey of recent accounts. PTL: A Journal for Descriptive Poetics and Theory of Literature 3, 249-278.

Mikkola, Kati, Lea Laitinen 2013. Mielen ja kielen muutoksia [Changes in mind and language]. In Laitinen, Lea \& Kati Mikkola (eds.), Kynällä kyntäjät: Kansan kirjallistuminen 1800-luvun Suomessa [Ploughing with pen: Processes of literacy from below in 19th-century Finland], 413-463. Helsinki: Finnish Literature Society.

$\mathrm{Nau}$, Nicole. 2006. Out of Africa: Logophoric pronouns and reported discourse in Finnish and High Latvian dialects. Acta Linguistica Lithuanica, LV, 55-87.

Nelson, Diane, Virve-Anneli Vihman. 2018. Shifting perspective: noun classes, voice, and animacy type shifts. Theoretical Linguistics. 44(1-2): 57-69

Pearson, Hazel. 2015. The Interpretation of the Logophoric Pronoun in Ewe. Natural Language Semantics 23(2), 77-118.

Peltola, Rea. 2018, this issue. Interspecies identification in nature observations: Modal expressions and open reference constructions with non-human animate reference in Finnish. Open Linguistics.

Priiki, Katri. 2017. The Finnish logophoric pronoun hän-a quantitative approach. Journal of Estonian and Finno Ugric Linguistics 8 (2), 327-349.

Priiki, Katri. 2016. Henkilöviitteisten kolmaspersoonaisten pronominien vaihtelu Satakunnan nykypuhekielessä keskutelukumppanin tuttuuden mukaan [The variation of Finnish third-person pronouns according to how closely the speakers are acquainted]. Puhe ja kieli, 36:2, 123-144.

Premack, David, Guy Woodruff. 1978. Does the chimpanzee have a "theory of mind"? Behavioral and Brain Sciences, 4, 515-526.

Rivinoja, Anne. 2006. The problem with pronouns in translated English FID into Finnish. In Pekka Tammi \& Hannu Tommola (eds.), FREE language INDIRECT translation DISCOURSE narratology. Linguistic, Translatological and Literary-Theoretical Encounters. Tampere Studies in Language, Translation and Culture. Series A 2. Tampere: Tampere University Press 2006, 115-133.

Rouhiainen, Tarja. 2000. Free Indirect Discourse in the Translation into Finnish: The Case of D.H. Lawrence's Women in Love. Target 12 (1):109-126

Sauerland, Uli. 2008. Implicated presuppositions. In Anita Steube (ed.), The discourse potential of underspecified structures, 581-600. Berlin: Mouton De Gruyter.

Saukkonen, Pauli. 1967. Persoonapronominen hän:se, he:ne distinktiivi oppositio [The distinctive opposition of the personal pronouns hän:se, he:ne] . Virittäjä 71:286-292.

Schlenker, Philippe. 1999. Propositional attitudes and indexicality: A cross-categorial approach. $\mathrm{PhD}$ dissertation, MIT.

Schlenker, Philippe. 2003. A plea for monsters. Linguistics and Philosophy, 26: 29-120

Sealey, Alison. 2018. Animals, animacy and anthropocentrism. International Journal of Language and Culture, 5, 224-247.

Sealey, Alison, Lee Oakley. 2013. Anthropomorphic grammar?: some linguistic patterns in the wildlife documentary series Life. Text and Talk, 33, 3, 399-420.

Sells, Peter. 1987. Aspects of logophoricity. Linguistic Inquiry 18(3):445-479.

Setälä, E.N. 1883. Lauseopillinen tutkimus Koillis-Satakunnan kansankielestä [A syntactic study of the dialect spoken in northeastern Satakunta]. Helsinki: Suomalaisen Kirjallisuuden Seura.

Siewierska, Anna. 2004. Person. Cambridge University Press.

Siitonen, Kirsti. 2008. Sävypronomini hän [Nuances of the personal pronoun hän]. Sananjalka 50, 87-109.

Stephenson, Tamina. 2007. Towards a theory of subjective meaning. PhD dissertation, MIT.

Sudo, Yasutada. 2012. On the Semantics of Phi Features on Pronouns. PhD dissertation, MIT.

Sulkala, Helena, Merja Karjalainen. 1992. Finnish. London and New York: Routledge.

Sundaresan, Sandhya. 2012. Context and (Co)reference in the syntax and its interfaces. PhD dissertation, University of Troms $\emptyset$ and University of Stuttgart.

Suonperä, Anni. 2012. Se, hän ja tekstityksen puhe: Pronominivariaatio elokuvakäänöksen puheen illuusiossa [Se 'it', hän 'he/she' and the speech of subtitles: Pronoun variation in the speech illusion of movie translations]. University of Tampere. Pro gradu (MA thesis).

De Swart, Peter, Helen de Hoop. 2018. Shifting animacy. Theoretical Linguistics, 44(1):1-23.

Teterina, Marina. 2012. The use of gendered pronouns with animal referents in English. Speech and context, vol 2 (IV), 1-10.

Tiittula, Liisa, Pirkko Nuolijärvi. (2013). Puheen illuusio suomenkielisessä kaunokirjallisuudessa [The illusion of speech in Finnish fiction]. Helsinki: Suomalaisen Kirjallisuuden Seura.

Varteva, Annukka. 1998. Pronominit hän ja tämä tekstissä [The pronouns hän 'he/she' and tämä 'this' in text]. Virittäjä 2/1998:202-223.

Vilppula, Matti. 1989. Havaintoja hän- ja he-pronominen käytöstä suomen murteissa. [Observations about the use of the pronouns hän 'he/she' and he 'they' in Finnish dialects] Virittäjä 93:389-399.

von Stechow, A. 2003. Feature deletion under semantic binding. In Proceedings of NELS 33, ed. M. Kadowaki, and S. Kawahara, 133-157. Amherst, MA: GLSA Publications. 
Waytz, Adam, John Cacioppo, Nicholas Epley. 2010a. Who sees Human? The stability and importance of individual differences in anthropomorphism. Perspectives on Psychological Science, Vol. 5(3):219-232.

Waytz, Adam, Kurt Gray, Nicholas Epley, Daniel Wegner. 2010b. Causes and consequences of mind perception. Trends in Cognitive Sciences, 14, 383-388.

Yanovich, Igor. 2012. Indexical presuppositions of pronominal gender features. Unpublished manuscript. http://www.sfs. uni-tuebingen.de/ yanovich/ [access: November 12, 2017]

Ylikahri, Kristiina. 1996. Referoinnin laajentumat hän-, he- ja se-, ne-pronominen käytössä Siikaisten murteessa. Virittäjä 100:182-203. 